\title{
Method for identifying effective carbonate source rocks: a case study from Middle-Upper Ordovician in Tarim Basin, China
}

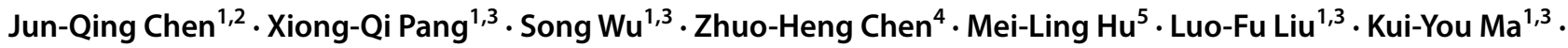 \\ Bo Pang ${ }^{1,3} \cdot$ Zhi-Peng Huo ${ }^{6}$
}

Received: 15 February 2020 / Published online: 19 September 2020

(c) The Author(s) 2020

\begin{abstract}
Hydrocarbon expulsion occurs only when pore fluid pressure due to hydrocarbon generation in source rock exceeds the force against migration in the adjacent carrier beds. Taking the Middle-Upper Ordovician carbonate source rock of Tarim Basin in China as an example, this paper proposes a method that identifies effective carbonate source rock based on the principles of mass balance. Data from the Well YW2 indicate that the Middle Ordovician Yijianfang Formation contains effective carbonate source rocks with low present-day TOC. Geological and geochemical analysis suggests that the hydrocarbons in the carbonate interval are likely self-generated and retained. Regular steranes from GC-MS analysis of oil extracts in this interval display similar features to those of the crude oil samples in Tabei area, indicating that the crude oil probably was migrated from the effective source rocks. By applying to other wells in the basin, the identified effective carbonate source rocks and non-source rock carbonates can be effectively identified and consistent with the actual exploration results, validating the method. Considering the contribution from the identified effective source rocks with low present-day TOC $\left(\mathrm{TOC}_{\mathrm{pd}}\right)$ is considered, the long-standing puzzle between the proved 3P oil reserves and estimated resources in the basin can be reasonably explained.
\end{abstract}

Keywords Effective carbonate source rock · Mass balance approach $\cdot$ Low present-day TOC $\cdot$ Ordovician · Tarim Basin

\section{Introduction}

Edited by Jie Hao

Jun-Qing Chen

cjq7745@163.com

$\triangle$ Xiong-Qi Pang

pangxqcup@163.com

1 State Key Laboratory of Petroleum Resources and Prospecting, China University of Petroleum, Beijing 102249, China

2 Beijing Key Laboratory of Optical Detection Technology for Oil and Gas, China University of Petroleum, Beijing 102249, China

3 College of Geoscience, China University of Petroleum, Beijing 102249, China

4 Geological Survey of Canada, Calgary, AB T2L 2A7, Canada

5 Research Institute of Petroleum Exploration and Development, PetroChina Huabei Oilfield Company, Renqiu 062550, Hebei, China

6 China University of Geosciences, Beijing 100083, China
In the past, scholars in the world have put forward different definitions of effective carbonate source rock. For example, Hunt (1995) regarded rocks that have generated and expelled hydrocarbon fluid as effective source rocks. Pang et al. (1993) considered only those rocks that expel freephase hydrocarbons in large quantities are effective source rocks. To be specific, only those rocks that contain sufficient organic matter (quantity) with good kerogen type (quality) at a certain thermal evolution stage (maturity) and that are capable of expelling sufficient hydrocarbons for forming commercial accumulations, are referred as effective source rocks. Depending on quality and maturity, the threshold of TOC value as an effective source rock varies. In the past, people proposed different threshold TOC values in carbonate rock, from $0.1 \%$ to $0.5 \%$, based on different methods in various basins (Table 1). For the convenience of discussion, we take $0.5 \%$ as the threshold value of present-day TOC $\left(\mathrm{TOC}_{\mathrm{pd}}\right)$ to define the high organic matter and low organic matter carbonate source rocks. For mature source rock, the 
Table 1 Various threshold of TOC value as an effective carbonate source rock from different authors

\begin{tabular}{lc}
\hline References & $\begin{array}{c}\text { Threshold of TOC value as an } \\
\text { effective carbonate source rock }\end{array}$ \\
\hline Chen (1985) and Qin et al. (2004) & 0.1 \\
Ronov (1958), Liu and Shi (1994) and Huo et al. (2019) & 0.2 \\
Hunt (1967) and Tissot and Welte (1978) & 0.3 \\
Palacas (1984) and Peng et al. (2008) & 0.4 \\
Qiu et al. (1998) and Zhang et al. (2002a, 2012) & 0.5 \\
\hline
\end{tabular}

$\mathrm{TOC}_{\mathrm{pd}}$ denotes the residue of organic matters in the source rocks after generation and expulsion, which does not represent the initial amount TOC prior to thermal decomposition. Jarvie (2014) shows that depending on the type of kerogen, up to $80 \%$ of original TOC $\left(\mathrm{TOC}_{\mathrm{o}}\right)$ can be converted to hydrocarbons. For example, Type I kerogen has initial hydrogen index $\mathrm{HI}_{\mathrm{o}}>700 \mathrm{mg} / \mathrm{g}$ (Jones 1984), which means that at least $58 \%$ TOC can be converted to hydrocarbons. Pang et al. (2014) attempted to restore the initial TOC value by introducing a recovery factor in a study of carbonate source rocks. Based on data from six petroliferous sedimentary basins in China, the recovery coefficient $\left(\mathrm{TOC}_{\mathrm{o}} /\right.$ $\mathrm{TOC}_{\mathrm{pd}}$ ) for Type I, Type II and Type III kerogen can reach $3.2,2.2$ and 1.5 , respectively.

Utilizing present-day TOC threshold as a measure for determining effective source rock is rather arbitrary, inconsistent and incomparable across source rock units, even for the same source rock with different thermal maturities. For example, Ronov (1958) suggested a TOC threshold of 1.4\% for shales in the Upper Devonian Formation in the Siberian platform. Organic geochemical and discoveries data indicated that the effective source rock of Paleogene Shahejie Formation in Jiyang Depression, Bohaibay Basin has a threshold of above 2\% (Wang et al. 2013). Due to the fact that the adsorption and retention capacities of carbonates are weaker than those of clays, Tissot and Welte (1984) took $0.3 \%$ as a threshold TOC value in carbonate source rocks based on empirical observations.

In defining an effective source rock, the quantity, quality and thermal maturity of kerogen are the three primary elements, in addition to the characteristics of conduits immediately in contacts with the source rock. However, the three elements compensate for each other, making a TOC threshold as the sole criterion inconsistent. For example, kerogens with better quality or higher thermal maturity could lower down the threshold of initial TOC for an effective source rock because of more organic matter for conversion or lighter hydrocarbon fluid products.

In this paper, we propose a method for identifying effective source rock in carbonates using mass balance approaches by quantifying hydrocarbon expulsion and use the Middle-Upper Ordovician source rock of Tarim Basin in China as a case study to illustrate the procedure and demonstrate the feasibility of the proposed method.

\section{Geological background, data and methodology}

\subsection{Geological background}

The Tarim Basin, the largest subaerial petroliferous basin in China, has been estimated of about $20 \times 10^{9}$ tons oil equivalent of hydrocarbon resources (Wang et al. 2015). In recent years, more discoveries have been made from the Ordovician carbonate successions in Yingmaili, Halahatang, Hudson, Xinken areas in Tabei Uplift and Tazhong Uplift (Fig. 1a), with the 3P reserves of $1.04 \times 10^{9}$ tons in Tazhong Uplift and $3.0 \times 10^{9}$ tons in Tabei Uplift, respectively. In contrast, an early resource appraisal based on source rock capacity indicated $3.794 \times 10^{9}$ tons oil equivalent hydrocarbon resources only (Yang 2012), smaller than what have been already discovered, a long-standing puzzle in the Tarim hydrocarbon exploration. Although geochemical studies suggest that hydrocarbons accumulated in the Ordovician succession are of geochemical signatures similar to typical hydrocarbons originated from the source rocks in Middle-Upper Ordovician (Fig. 1b) (Zhang et al. 2000, 2002b, 2004; Wang and Xiao 2004; Zhang et al. 2007; Zhao et al. 2008; Li et al. 2008; Wang et al. 2014), more than 200 prospecting wells penetrated the Middle-Upper Ordovician succession show limited high $\mathrm{TOC}_{\mathrm{pd}}$ source rock beds across the basin (Fig. 1c). The carbon deficit in mass balance implies additional sources, perhaps from the low-TOC ${ }_{\mathrm{pd}}$ source rock beds contributing to the discovered reserves (Huo et al. 2013; Pang et al. 2014; Liu et al. 2017).

From bottom to top, the Ordovician stratigraphic sequences in the Tarim Basin are the Lower Ordovician Yingshan Formation $\left(\mathrm{O}_{1} y\right)$, the Middle Ordovician Yijianfang Formation $\left(\mathrm{O}_{2} y\right)$, the Tumuxiuke Formation $\left(\mathrm{O}_{3} t\right)$, the Lianglitage Formation $\left(\mathrm{O}_{3} l\right)$ and the Upper Ordovician Sangtamu Formation $\left(\mathrm{O}_{3} t\right)$ (Fig. 1b). Among the formations, the Sangtamu Formation is dominated by clastic rocks, 

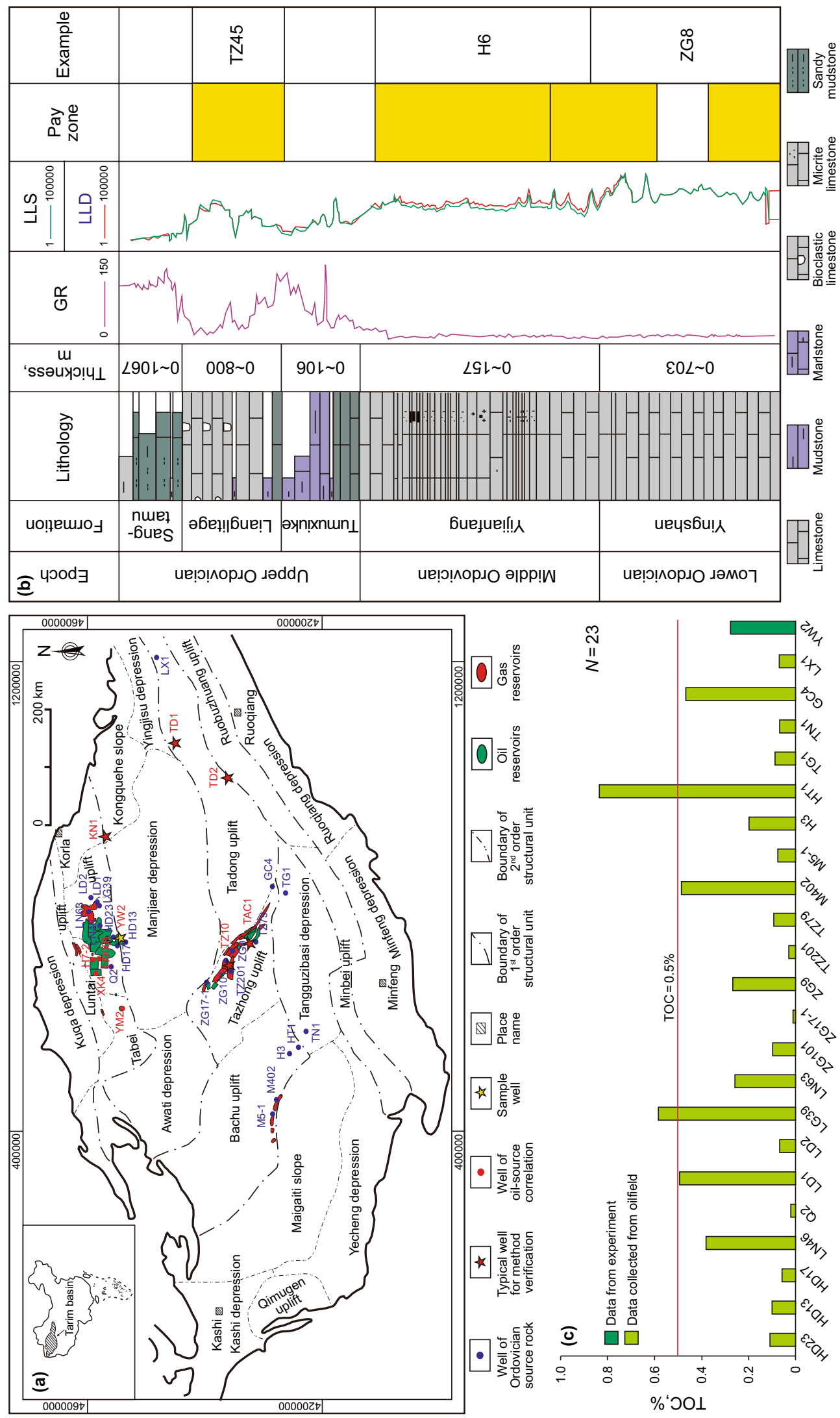

Fig. 1 The distribution of discovered hydrocarbon and Ordovician source rocks, Tarim Basin. a The distribution of discovered hydrocarbons, Tarim Basin; $\mathbf{b}$ stratigraphic framework of the Ordovician System in the Platform of the Tarim Basin; $\mathbf{c}$ The present-day measured TOC values of the Upper-Middle Ordovician source rocks (the locations of sample wells are shown in a) 
while the other formations are mainly composed of carbonate rocks.

The Yangwu 2 (YW2) well, located to the west of Yangwu 2 (YW2) structure in the Manbei structural zone in the north of Manjiaer depression, Tarim Basin (Fig. 1a), has been studied to investigate the generation potential of the Middle-Upper Ordovician source rocks in recent years (Zhu et al. 2011). This well is also chosen as a case in this study because of two reasons, (a) continuous sampling of every meter for entire interval of interested; and (b) deepest penetration reaching the Middle Ordovician carbonate. Eighty six samples were taken from the entire Ordovician interval penetrated from $6411 \mathrm{~m}$ to $6496 \mathrm{~m}$ (vitrinite reflectance equivalent from $1.3 \%$ to $1.4 \%$ ), and among them, fluorescence, oil stain and oil shows can be found easily.

\subsection{Experiments and data}

QA/QC were preliminarily conducted on samples to ensure the representativeness and free of contaminations from artifacts. During sample preparation, the samples were cleaned first with distilled water in order to dispel any annexing agents from drilling mud. The samples were crushed to 80 mesh after drying for $5 \mathrm{~h}$ at $55^{\circ} \mathrm{C}$ and then sealed in glass bottles for further examinations.

Two laboratory experiments are conducted in this study: TOC content analysis and Rock-Eval pyrolysis. In order to guarantee experimental quality, a finely GBW(E)070037a sample in powder form with TOC of $2 \%, S_{2}$ of $8.2 \pm 0.3 \mathrm{mg} / \mathrm{g}$ and $T_{\max }$ of $439 \pm 2{ }^{\circ} \mathrm{C}$ was selected as the standard. To keep the consistency, the standard sample was analyzed both at commence and end of each batch of samples as well as between every five samples within each batch.

In the TOC analysis, each sample was taken weighted $100 \mathrm{mg}$ and the CS-230HC machine produced by LECO Company of USA was utilized. Dilute hydrochloric acid was dripped onto the samples to get rid of inorganic carbons until no bubbles were formed. And then distilled water was used to rinse simples multiple times for neutralizing hydrochloric acid in the samples. Finally, those samples were exsiccated at a low temperature around $40{ }^{\circ} \mathrm{C}$ and incinerated with oxygen at a high temperature for the conversion of TOC content to $\mathrm{CO}_{2}$. Infrared detector was used to measure the $S_{2}$ experimental signal.

In order to conduct Rock-Eval pyrolysis experiment, the amount of free $S_{1}$ and pyrolyzed hydrocarbons and the highest pyrolysis temperature $\left(T_{\max }\right)$ can be acquired by Rock-Eval 6 instrument. The beginning temperature of pyrolysis procedure was set to be $300{ }^{\circ} \mathrm{C}$ and held for $3 \mathrm{~min}$. Further, the increasing rate of temperature was set at $25^{\circ} \mathrm{C}$ per minute until temperature reaching $650{ }^{\circ} \mathrm{C}$. Finally, the temperature decreases naturally.

The GC-MS analysis results for the interval from the YW2 well (4 samples) and those of discovered oils in the Yingmaili (3 samples) and Halahatang oilfields (3 samples) in the Tabei area are collected from the Tarim Oilfield Company, PetroChina. The sample locations are shown in Fig. 1a. Other data, including reservoir volumetric parameters, oil density, water salinity, formation pressure and temperature and others, are also collected from the company in the study.

\subsection{Principle and methodology}

Pang et al. (1993, 2005) and Pang (1995) discussed the concept of hydrocarbon expulsion threshold based on mass balance theory which mean the sum of hydrocarbon generation, reservation and expulsion keeps constant in a source rock system. The expulsion threshold is defined as a quantity of hydrocarbon generated in a source rock system, at which the induced over-pressure caused by fluid expansion exceeds capillary force and causes massive hydrocarbon migration out of the source rock into carrier beds under a new hydrodynamic equilibrium (Pang et al. 1993, 2005; Pang 1995) (Fig. 2). Thus, an effective source rock is defined the one that has expelled large quantity of hydrocarbon fluids and the expulsion threshold is used to identify effective source rock. The expulsion threshold can be described by geological conditions such as depth $(H)$, organic type, thermal maturity $\left(R_{\mathrm{o}}\right)$ and organic abundance (TOC), critical saturation of expulsion $\left(S_{\mathrm{o}}\right)$. All definitions of the variables mentioned in this study are introduced in the Table 2.

In the Middle-Upper Ordovician case study of the Tarim Basin, the determination of effective source rock is based on the balance between quantity of hydrocarbon generated and quantity of hydrocarbon required by primary migration (Pang et al. 1993, 2005; Pang 1995). If the quantity of hydrocarbon generated is reached or greater than the expulsion threshold, the source rock is regarded as effective that contributed to hydrocarbon accumulation in the region. In this paper, the expulsion threshold is estimated from a statistical model that was established on large number of observations in well-studied petroleum-bearing sedimentary basins in China (Pang et al. 2005). The hydrocarbon expulsion threshold is determined where the hydrocarbon generation potential in Fig. 2, the envelope curve of data points of $\left(\left(S_{1}+S_{2}\right) /\right.$ TOC) $\times 100$, reaches its maximum value (Pang et al. 2005). When source rocks are buried deeper than the hydrocarbon expulsion threshold, hydrocarbons are expelled from source rocks, and the hydrocarbon generation potential decreases (Chen et al. 2020). 


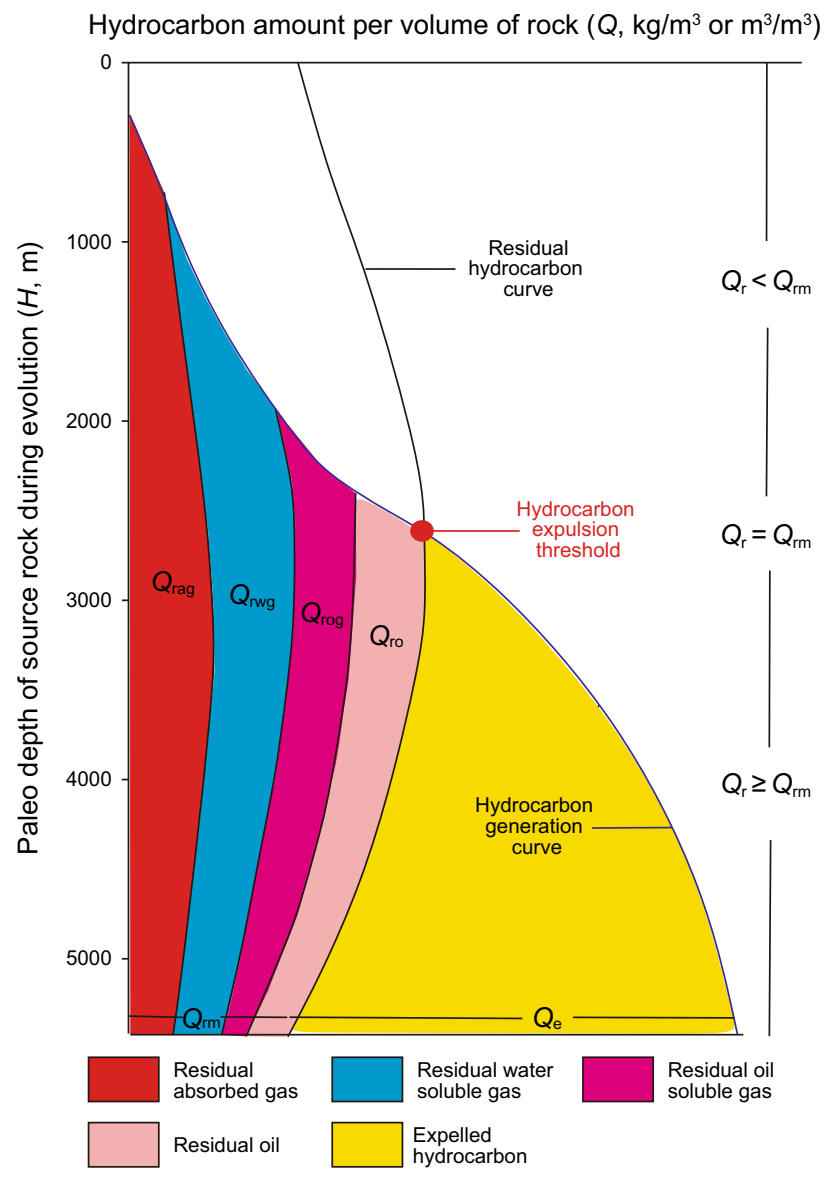

Fig. 2 Mass balance model of hydrocarbon generation, residue, expulsion variation of source rock (modified from Pang et al. 1993). Before hydrocarbon expulsion threshold, all of the hydrocarbons are retained in source rock since the fluids are not enough to be able to migrate against capillary sealing; at the hydrocarbon expulsion threshold, fluids in source rock are sufficient to trigger the secondary migration and the expulsion amount is zero; after the hydrocarbon expulsion threshold, source rock expels movable hydrocarbons, and expulsion amount would increase with growing maturity and might gradually decrease when exhausting its ability to generate hydrocarbons either through lack of sufficient organic matter or due to reaching an over mature state

\subsection{Model for calculating hydrocarbon expulsion threshold}

According to the previous study (Pang et al. 1993, 2005; Pang 1995; Jiang et al. 2002, 2006), residual hydrocarbons in source rocks mainly include liquids, free and adsorbed gases, water-soluble and oil-soluble gases (Fig. 2, Eq. 1):

$Q_{\mathrm{rm}}=Q_{\mathrm{ro}}+Q_{\mathrm{rag}}+Q_{\mathrm{rwg}}+Q_{\mathrm{rog}}$

where $Q_{\mathrm{rm}}, \mathrm{kg} / \mathrm{m}^{3}$, is quantity of hydrocarbon in a single unit volume of source rock at expulsion threshold; $Q_{\mathrm{ro}}, \mathrm{kg} /$ $\mathrm{m}^{3}$, is quantity of liquid residual hydrocarbon in a single unit volume of rock at expulsion threshold; $Q_{\text {rag }}, \mathrm{kg} / \mathrm{m}^{3}$, is quantity of absorbed gas in a single unit volume; $Q_{\mathrm{rwg}}, \mathrm{kg} /$ $\mathrm{m}^{3}$, is quantity of water-soluble gas in a single unit volume; and $Q_{\text {rog }}, \mathrm{kg} / \mathrm{m}^{3}$, is quantity of oil-soluble gas in a single unit volume. All the quantities are measured at the expulsion threshold in source rock.

(1) Calculation of liquid hydrocarbons $\left(Q_{\mathrm{ro}}\right)$ at expulsion threshold

Pang et al. (1993) analyzed the liquid residual hydrocarbons in source rocks and their relationship with major geological controlling factors based on the real data from Songliao Basin, Hailaer Basin and Tarim Basin in China and established a statistical model for estimating the quantity of liquid residual hydrocarbons at the expulsion threshold in the source rock. The model has the following form:

$Q_{\mathrm{ro}}=\rho_{\mathrm{o}} \cdot\left(\varphi_{\mathrm{n}}+\Delta \varphi\right) \cdot S_{\mathrm{om}}$

$S_{\mathrm{om}}=f(C \%) \cdot e^{-\varphi_{\mathrm{n}}\left(R_{\mathrm{o}}-R^{\prime}\right)^{2} / D} /\left(1-B_{\mathrm{k}}\right)$

$f(C)=A_{0}+A_{1} \cdot C+A_{2} \cdot(C)^{2}$

$B_{\mathrm{k}}=0.81-1.05 R_{\mathrm{o}}+0.18\left(R_{\mathrm{o}}\right)^{2}$

where $\varphi_{\mathrm{n}}, \%$, is porosity in normal compaction state; $\Delta \varphi$ is residual porosity in under compacted state; $S_{\text {om }}, \%$, is saturation of liquid residual hydrocarbon in source rock. $f(C)$ is correlation factor of organic matter abundance and liquid residual hydrocarbon amount in source rock; $B_{\mathrm{k}}, \%$, represents the proportion of light hydrocarbons in liquid hydrocarbons; $C, \%$, represents organic matter content; $R_{\mathrm{o}}$, $\%$, represents vitrinite reflectance; $\rho_{\mathrm{o}}, \mathrm{kg} / \mathrm{m}^{3}$, is density of liquid residual hydrocarbons; $A_{0}, A_{1}, A_{2}, D$ and $R$ ' are undetermined constants concerning the characteristics of the source rocks in the study area.

(2) Calculation of absorbed gas at expulsion threshold $\left(Q_{\text {rag }}\right)$

The absorbed gas at expulsion threshold can be estimated using the following expression:

$Q_{\mathrm{rag}}=\sum_{i=1}^{4} Q_{\mathrm{ra} i} \cdot \rho_{\mathrm{g}}$

where $Q_{\text {rai }}, \mathrm{m}^{3} / \mathrm{m}^{3}$, is quantity of residual absorbed hydrocarbon component $i$ in a signal unit volume of rock; $i$ represents the $i^{\text {th }}$ component of gaseous hydrocarbons, such as $\mathrm{CH}_{4}$, $\mathrm{C}_{2} \mathrm{H}_{6}, \mathrm{C}_{3} \mathrm{H}_{8} ; \rho_{\mathrm{g}}, \mathrm{kg} / \mathrm{m}^{3}$, is density of gaseous hydrocarbons. 
The amount of absorbed gas is mainly related to source rock properties (organic matter abundance, organic matter type, organic matter maturity, mineral components and specific surface areas), formation pressure and temperature, gaseous hydrocarbon components and concentration and other factors (Dubinin 1960; Schettler et al. 1991; Robert and Zoback 2014; Ross and Bustin 2009). Pang et al. (1993) analyzed the influence of each of the factors in a relation to the absorbed hydrocarbon component $i$ based on the data collected from Songliao Basin, Hailaer Basin and Tarim Basin in China. An empirical model was established to simulate the amount of absorbed gas component $i$ amount. The model can be expressed quantitatively in the following equations (Pang et al. 1993; Tian et al. 2010):

$Q_{\mathrm{ra} i}=K_{i} \cdot \rho_{\mathrm{r}} \cdot K(C \%) \cdot K\left(R_{\mathrm{o}}\right) / K_{\mathrm{w}} \cdot a_{i} \cdot b_{i} \cdot P \cdot e^{-n(T-20)} /\left(1+b_{i} \cdot P\right)$

$n=0.02 /(0.993+0.0017 P)$

$K\left(R_{\mathrm{o}}\right)=0.836+0.68\left(R_{\mathrm{o}}\right)+0.498\left(R_{\mathrm{o}}\right)^{2}$

$K(C)=B_{0}+B_{1} \cdot C$

$K_{\mathrm{w}}=1+0.445 e^{1-P}$

$K_{i}=\left\{\begin{array}{c}0.079 \\ 0.00478 \\ 0.0066 \\ 0.0038\end{array} a_{i}=\left\{\begin{array}{l}0.117 \\ 0.723 \\ 1.309 \\ 1.833\end{array} b_{i}=\left\{\begin{array}{c}5.32 \\ 0.15 P+0.30 \\ 3.04 P+0.6858 \\ 8.688 P+1.065\end{array} i=\left\{\begin{array}{c}\mathrm{CH}_{4} \\ \mathrm{C}_{2} \mathrm{H}_{6} \\ \mathrm{C}_{3} \mathrm{H}_{8} \\ \mathrm{C}_{4} \mathrm{H}_{10}\end{array}\right.\right.\right.\right.$

where $n$ means correlation factor related to pressure, as an integer; $T,{ }^{\circ} \mathrm{C}$, represents formation temperature; $P, \mathrm{~Pa}$, is formation pressure; $C, \%$, refers to organic matter content; $R_{\mathrm{o}}, \%$, means vitrinite reflection; $K_{\mathrm{w}}$ is wettability, dimensionless; $K(C)$ is correlation factor between organic matter abundance and absorbed gas amount in source rock; $K\left(R_{\mathrm{o}}\right)$ is correlation factor between thermal maturity and absorbed gas amount in source rock; $K_{i}$ is correlation factor between hydrocarbon component and absorbed gas amount in source rock; $i$ represents the $i^{\text {th }}$ component of gaseous hydrocarbons such as $\mathrm{CH}_{4}, \mathrm{C}_{2} \mathrm{H}_{6}, \mathrm{C}_{3} \mathrm{H}_{8}$ and $\mathrm{C}_{4} \mathrm{H}_{10} ; \rho_{\mathrm{r}}, \mathrm{kg} / \mathrm{m}^{3}$, is density of source rocks; and $B_{0}$ and $B_{1}$ are related coefficients for the relationship between absorbtion ability of source rocks and organic carbon content.

(3) Calculation of water-soluble gas $\left(Q_{\mathrm{rwg}}\right)$ at expulsion threshold.

The calculation model of water-soluble gas can be expressed as follows:
$Q_{\mathrm{rwg}}=\sum_{i=1}^{4} Q_{\mathrm{rwg} i} \cdot \rho_{\mathrm{g}}$

$Q_{\mathrm{rwg} i}=q_{\mathrm{w}}(i) \cdot \varphi \cdot\left(1-S_{\mathrm{o}}\right)$

where $Q_{\mathrm{rwgi}}, \mathrm{m}^{3} / \mathrm{m}^{3}$, is water-soluble hydrocarbon component $i$ in pore water; $i$ represents different components of gaseous hydrocarbons such as $\mathrm{CH}_{4}, \mathrm{C}_{2} \mathrm{H}_{6}, \mathrm{C}_{3} \mathrm{H}_{8} ; \rho_{\mathrm{g}}, \mathrm{kg} / \mathrm{m}^{3}$, is density of gaseous hydrocarbons; $q_{\mathrm{w}}(i), \mathrm{m}^{3} / \mathrm{m}^{3}$, is soluble gaseous hydrocarbon component $i$ amount in formation water; $\varphi, \%$, is source rock porosity; $S_{0}, \%$, is fluid residual hydrocarbon flow saturation in source rock.

In their study, an empirical model was also established to estimate gas component $i$ amount in formation water, which is displayed as follows (Pang et al. 1993; Tian et al. 2010).

$$
\begin{aligned}
& q_{\mathrm{w}}(i)=q_{\mathrm{w}}\left(1, T, P, X_{\mathrm{K}}\right) \cdot q_{\mathrm{w}}(i, T, P) / q_{\mathrm{w}}(1, T, P) \\
& q_{\mathrm{w}}\left(1, T, P, X_{\mathrm{K}}\right)=\left(1.15 \cdot 0.005 \cdot T^{1.33} \cdot 22.4 / 16\right) \\
& \cdot\left(0.994-0.0032 \cdot X_{\mathrm{K}}+0.0007 \cdot T\right)
\end{aligned}
$$

$q_{\mathrm{w}}(i, T, P)=a_{0 i}+a_{1 i} \cdot P+a_{2 i} \cdot T+a_{3 i} \cdot P^{2}+a_{4 i} \cdot T^{2}+a_{5 i} \cdot P \cdot T$

$$
\left\{\begin{array} { c } 
{ a _ { 0 1 } = 2 . 4 1 6 } \\
{ a _ { 1 1 } = 0 . 0 0 9 6 1 } \\
{ a _ { 2 1 } = - 0 . 0 3 4 8 } \\
{ a _ { 3 1 } = - 1 . 0 4 \times 1 0 ^ { - 5 } } \\
{ a _ { 4 1 } = 9 . 0 5 \times 1 0 ^ { - 7 } } \\
{ a _ { 5 1 } = 6 . 1 4 \times 1 0 ^ { - 5 } }
\end{array} \left\{\begin{array} { c } 
{ a _ { 0 2 } = 1 . 2 2 9 } \\
{ a _ { 1 2 } = 0 . 0 0 1 3 7 } \\
{ a _ { 2 2 } = - 0 . 0 1 7 5 } \\
{ a _ { 3 2 } = - 3 . 8 7 \times 1 0 ^ { - 6 } } \\
{ a _ { 4 2 } = 3 . 9 4 \times 1 0 ^ { - 7 } } \\
{ a _ { 5 2 } = 3 . 2 7 \times 1 0 ^ { - 5 } }
\end{array} \left\{\begin{array}{c}
a_{03}=0.231 \\
a_{13}=0 \\
a_{23}=0 \\
a_{33}=-3.31 \times 10^{-6} \\
a_{43}=4.26 \times 10^{-7} \\
a_{53}=1.141 \times 10^{-5}
\end{array}\right.\right.\right.
$$

where $q_{\mathrm{w}}(i), \mathrm{m}^{3} / \mathrm{m}^{3}$, is soluble gaseous hydrocarbon component $i$ amount in formation water; $T,{ }^{\circ} \mathrm{C}$, represents the formation temperature; $P, \mathrm{MPa}$, is the formation pressure; $X_{\mathrm{K}}, \mathrm{g} / \mathrm{L}$, means salinity of formation water; $q_{\mathrm{w}}\left(1, T, P, X_{\mathrm{K}}\right)$ is variance of methane solubility in water controlled by pressure, temperature and water salinity; $q_{\mathrm{w}}(1, T, P)$ is solubility of gaseous hydrocarbon component $i$ in pore water controlled by pressure, temperature and water salinity.

(4) Calculation for oil-soluble hydrocarbon $\left(Q_{\text {rog }}\right)$ at expulsion threshold

The calculation model of oil-soluble gas amount can be expressed as follows:

$Q_{\mathrm{rog}}=\sum_{i=1}^{4} Q_{\mathrm{rog} i} \cdot \rho_{\mathrm{g}}$ 
$Q_{\mathrm{rog} i}=q_{\mathrm{o}}(i) \cdot \varphi \cdot S_{\mathrm{o}}$

where $Q_{\text {rogi }}, \mathrm{m}^{3} / \mathrm{m}^{3}$, is quantity of oil-soluble hydrocarbons component $i$ in pore oil; $i$ represents component of gaseous hydrocarbons such as $\mathrm{CH}_{4}, \mathrm{C}_{2} \mathrm{H}_{6}, \mathrm{C}_{3} \mathrm{H}_{8}, \mathrm{~kg} / \mathrm{m}^{3} ; q_{\mathrm{o}}(i), \mathrm{m}^{3} / \mathrm{m}^{3}$, is quantity of gaseous hydrocarbons component $i$ dissolved in liquid hydrocarbons; $\varphi, \%$, is source rock porosity; $S_{0}, \%$, is fluid residual hydrocarbon flow saturation in source rock.

Previous study shows that pore pressure and formation temperature are the two major geological factors controlling the amount of residual oil-soluble gaseous hydrocarbons. Based on the findings, Pang et al.(1993) built a corresponding model to simulate residual gas constituent $i$ amount in oil per volume of rock based on the experiments and study that is displayed as follows (Pang et al. 1993; Tian et al. 2010).

$q_{\mathrm{o}}(i)=4.95 \cdot K(i) \cdot K\left(\rho_{\mathrm{o}}\right) \cdot q_{\mathrm{og}}(T, P)$

$K(i)=(A(i)+B(i) \cdot P) / 100$

$K\left(\rho_{\mathrm{o}}\right)=1.75-1.8 \cdot \rho_{\mathrm{o}}$

$q_{\mathrm{og}}(T, P)=-0.726+0.387 \cdot P-0.0323 \cdot T$

$\left\{\begin{array}{c}A(1)=62.63 \\ A(2)=18.68 \\ A(3)=9.89 \\ A(4)=4.203\end{array}\left\{\begin{array}{l}B(1)=0.00716 \\ B(2)=0.00365 \\ B(3)=0.00212 \\ B(4)=0.00085\end{array}\right.\right.$

where $q_{\mathrm{o}}(i), \mathrm{m}^{3} / \mathrm{m}^{3}$, is quantity of gaseous hydrocarbons component $i$ dissolved in liquid hydrocarbons in a signal unit volume; $q_{\mathrm{og}}(T, P), \mathrm{m}^{3} / \mathrm{m}^{3}$, is the gaseous hydrocarbon in liquid hydrocarbons, an empirical function of temperature and pressure conditions; $K(i)$ is proportion of component $i$ of gaseous hydrocarbons dissolved in liquid hydrocarbons, decimal; $K\left(\rho_{\mathrm{o}}\right)$ is calibration factor reflecting variation of oil-soluble gaseous hydrocarbons with oil density, as an integer; $\rho_{\mathrm{g}}, \mathrm{kg} / \mathrm{m}^{3}$, is density of gaseous hydrocarbons; $T$, ${ }^{\circ} \mathrm{C}$, represents the formation temperature; and $P$, Mpa, represents the formation pressure.

\subsection{Model for calculating actual residual hydrocarbon amount}

Generally, chloroform bitumen 'A' and ' $S_{1}$ ' obtained through extraction and pyrolysis experiments were used to represent actual residual hydrocarbon amount. Chloroform 'A' refers to residual hydrocarbons extracted by chloroform organic solvent, the unit being a proportion of the weight of extraction to that of rock. ' $S_{1}$ ' is measured hydrocarbons from Rock-Eval pyrolysis when the rock is heated at $300{ }^{\circ} \mathrm{C}$. However, these two approaches for measuring actual residual hydrocarbon amount are not perfect. During the sampling and sample preparation, gaseous residual hydrocarbons are inevitably easily lost on the surface (Jiang et al. 2016). Therefore, gaseous hydrocarbons amount in rock is mostly not included in the parameters 'A' or ' $S_{1}$ '. Furthermore, change in temperature and pressure causes certain light liquid hydrocarbons to be released, especially those with carbon atoms fewer than 15 . In conclusion, residual hydrocarbons contained in ' $S_{1}$ ' and 'A' are only a portion of actual residual hydrocarbons in rocks. The components and loss amount vary with different lithologies. The maximum hydrocarbon evaporative loss rate can be up to $80 \%$ $\left(R_{\mathrm{o}} \leq 1.3 \%\right)$ by Chen et al. (2018) of Type I kerogen. The study result is consistent with that by Xue et al. (2016) of $76 \%$ loss rate through kinetic study of hydrocarbon generation. When $R_{\mathrm{o}}>1.3 \%$, the hydrocarbon evaporative loss rate would increase with increasing $R_{\mathrm{o}}$ as more oil crack to gaseous and light hydrocarbons that are more susceptible to evaporative loss. In addition, compared to 'A', ' $S_{1}$ ' contains more scarce residual hydrocarbons, as a consequence of ' $S_{1}$ ', representing only the hydrocarbons released before heating at $300{ }^{\circ} \mathrm{C}$, while constituents with larger molecular weight or high polarity remain in the rocks. Therefore, light hydrocarbon compensation calibration is necessary to offset these losses when calculating actual residual hydrocarbon amount using 'A' and ' $S_{1}$ '.

The actual residual hydrocarbons amount $\left(Q_{\mathrm{r}}\right)$ was calculated according to ' $S_{1}$ ' in this study based on the Rock-Eval pyrolysis results of representative samples chosen. The light hydrocarbons component was compensated in ' $S_{1}$ ' according to Pang et al. (1993), and the amount of actual residual hydrocarbons was calculated, utilizing the calibrated residual amount $\left(S_{1+}\right)$ according to the equations displayed as follows:

$S_{1+}=S_{1} /\left(1-B_{\mathrm{k}}\right)$

$Q_{\mathrm{r}}=S_{1+} \cdot \rho_{\mathrm{r}}$

where $S_{1+}, \mathrm{mg} / \mathrm{g}$, is actual residual liquid hydrocarbon amount considering light hydrocarbons; $S_{1}, \mathrm{mg} / \mathrm{g}$, is the free hydrocarbon amount acquired through pyrolysis experiments; $B_{\mathrm{k}}, \%$, refers to percent by weight of light hydrocarbons in entire liquid hydrocarbon; as shown in Eq. $5 ; \rho_{\mathrm{r}}, \mathrm{kg} /$ $\mathrm{m}^{3}$, is the density of source rocks. 


\section{Results}

\subsection{Parameters for study area}

There are some essential geological parameters data for the simulation of theoretical residual hydrocarbon amount at expulsion threshold and calculation of actual residual hydrocarbon amount, including crude oil density, porosity, total organic carbon, vitrinite reflectance, natural gas density, source rock density, formation temperature, formation pressure, oil saturation and formation water salinity.

\section{(1) Crude oil density}

Increase in depth leads to a rise in formation temperature, which leads to a decreasing trend of crude oil density (Fig. 3a). The relationship between oil density and depth can be fitted as follows, according to 893 measured crude oil density data from carbonate reservoirs in Tarim Basin's platform:

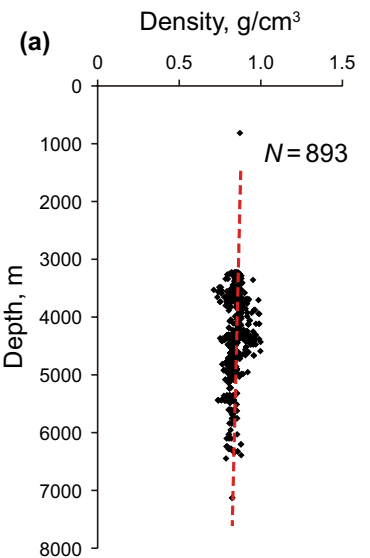

(e) Pressure, $\mathrm{MPa}$
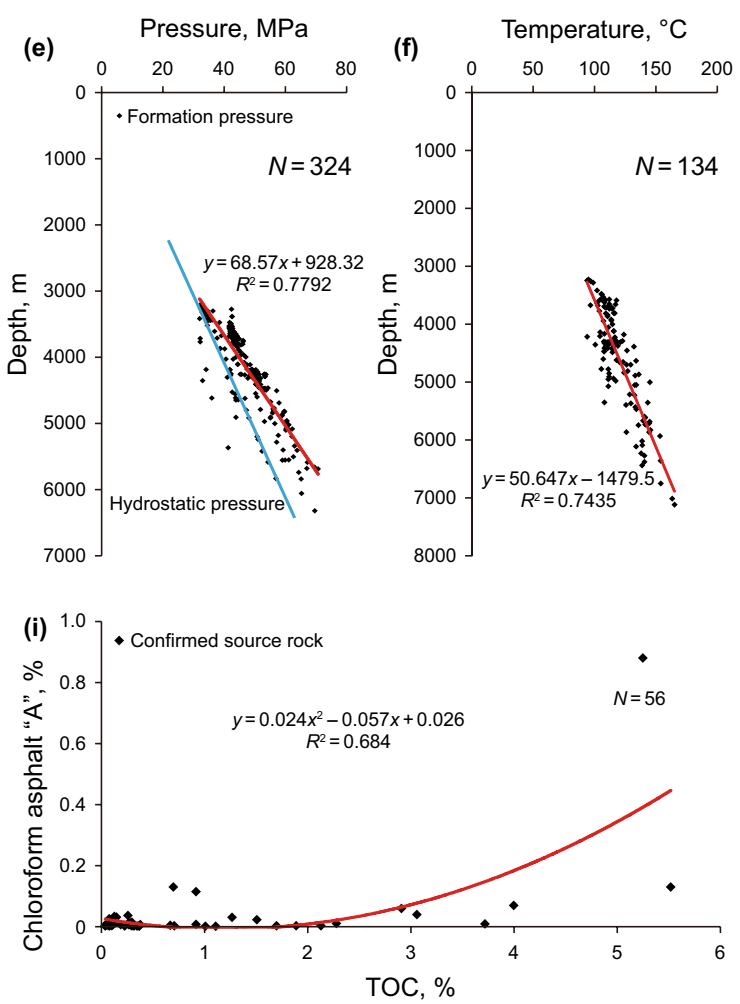

(b)

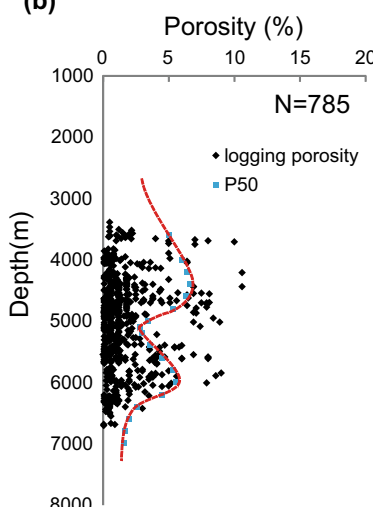

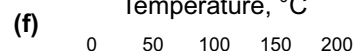

(c)

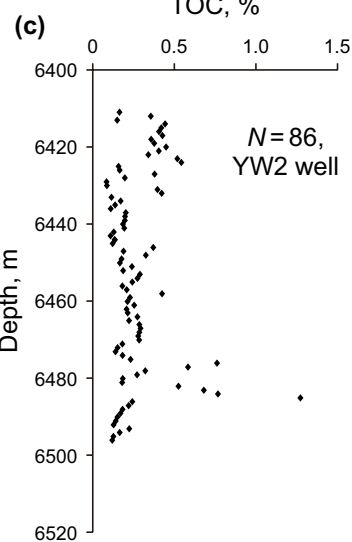

(g) Oil sauration, \%
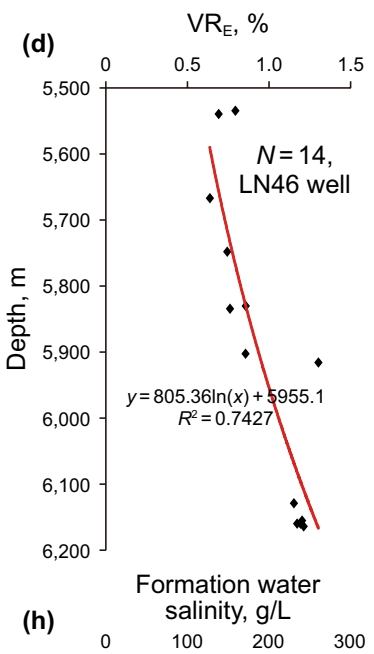
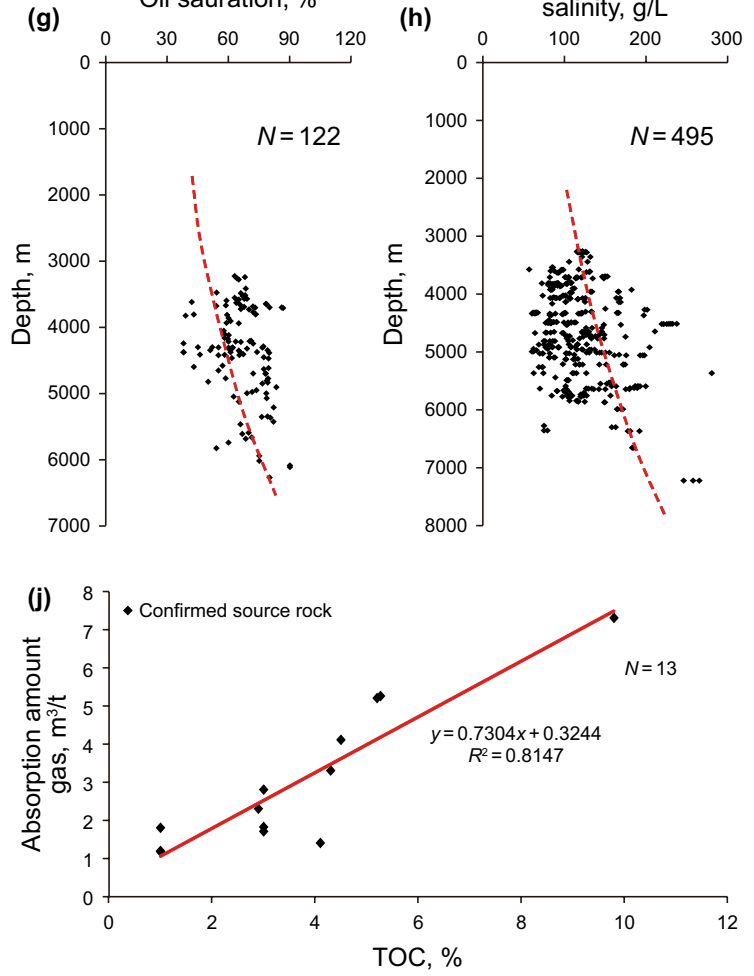

Fig. 3 Parameters of carbonate rocks in the platform of Tarim Basin. a Relationship between oil density and depth; b relationship between porosity and depth; c relationship between TOC and depth of YW2 well; d relationship between VRE and depth of carbonate rocks in LN46 well; e relationship between pressure and depth; $\mathbf{f}$ relationship between temperature and depth; $\mathbf{g}$ relationship between oil saturation and depth; $\mathbf{h}$ relationship between formation water salinity and depth; $\mathbf{i}$ relationship between "A" and TOC of confirmed typical source rock; $\mathbf{j}$ relationship between gas absorption amount and TOC of confirmed typical source rock (absorption experiment data) 
$\rho_{\mathrm{o}}=-7.7 * 10^{-6} H+0.88$

where $\rho_{\mathrm{o}}, \mathrm{g} / \mathrm{cm}^{3}$, is crude oil density; and $H, \mathrm{~m}$, refers to depth.

\section{(2) Porosity}

Along with increasing depth, the porosity of carbonate rocks in Tarim Basin's platform present two relative large areas, in which the porosity values gradually increase to a maximum due to karstification under unconformity surfaces (Lin et al. 2012) and carbonate rock dissolution by acidoid since hydrocarbon was generated and expelled (Surdam et al. 1984; Eseme et al. 2012) then decreases to a normal matrix porosity (Fig. 3b). The relationship can be obtained by 785 logging porosity data of local dry layers with different depth in Tarim Basin's platform, and it can be fitted as per the two binomials:

$\varphi=2.2 \times 10^{-6} H^{2}+1.7 \times 10^{-2} H-28.63, H<5100$

$\varphi=3.1 \times 10^{-6} H^{2}+3.6 \times 10^{-2} H-101.35, H \geq 5100$

where $\varphi, \%$, is formation porosity; and $H, \mathrm{~m}$, refers to depth.

\section{(3) TOC}

The total organic carbon (TOC) data of source rocks were obtained from 86 measured data by the experiment designed during the study (Fig. 3c); the location and experimental methods are shown in Sect. 2.1.

\section{(4) Vitrinite equivalent}

There is an obvious relationship between vitrinite equivalent $\left(\mathrm{VR}_{\mathrm{E}}\right)$ and depth of marine source rocks in Tarim Basin platform, wherein $\mathrm{VR}_{\mathrm{E}}$ appears to exponentially increase with depth (Fig. 3d). Due to lack of measured values for vitrinite equivalent of YW2 well, that of LN46 well was used, since which is located in the Tabei Uplift and displays the same tectonic setting as $\mathrm{YW} 2$ well. The relationship between $\mathrm{VR}_{\mathrm{E}}$ and depth is well fitted by using 14 practically measured vitrinite equivalent data from LN46 well in the Tabei Uplift, which can be expressed as:

$\mathrm{VR}_{\mathrm{E}}=0.00405 \mathrm{e}^{0.00092 H}$

where $\mathrm{VR}_{\mathrm{E}}, \%$, is vitrinite equivalent, and $H, \mathrm{~m}$, refers to depth.

(5) Pressure

The carbonate Cambrian and Ordovician Systems in Tarim Basin show a normal pressure and a little overpressure feature (Fig. 3e). The relationship between formation pressure and depth in Tarim Basin's platform is obtained based on 324 measured formation pressure data with different depths, which is displayed as follows.

$P=0.011 H-0.416$

where $P, \mathrm{MPa}$, is pressure, and $H$, $\mathrm{m}$, refers to depth.

\section{(6) Temperature}

In general, temperature increases linearly with depth (Fig. 3f). The formation temperature of Tarim Basin's platform can be calculated according to 134 actual temperature data with different depth. The relationship between temperature and depth is displayed below:

$T=0.014 H+52.31$

where $T,{ }^{\circ} \mathrm{C}$, is temperature; and $H, \mathrm{~m}$, refers to depth.

(7) Oil saturation

As shown in Fig. 3g, with increasing depth porosity decreases and oil saturation increases. According to 122 measured data with different depth, the relationship was determined in Tarim Basin's platform as below:

$S_{\mathrm{o}}=0.5608 \cdot \ln (H)-4.074$

where $S_{\mathrm{o}}, \%$, is oil saturation; and $H, \mathrm{~m}$, refers to depth.

(8) Formation water salinity

It can be easily seen that formation water salinity increases with depth in Tarim Basin's platform (Fig. 3h). Due to lack of data on source rock water salinity, that of reservoir rocks could be used, while carbonate rock is both source rock and reservoir. The following equation describes the relationship between formation water salinity and depth, based on 494 measured formation water salinity data:

$X_{\mathrm{K}}=25.563 \mathrm{e}^{0.0003 H}$

where $X_{\mathrm{K}}, \mathrm{g} / \mathrm{L}$, is formation water salinity, and $H, \mathrm{~m}$, refers to depth.

(9) Other parameters and coefficients

Other parameters used for calculations were adopted from empirical data of Tarim oilfield. For example, natural gas density is taken at an average of $0.71 \mathrm{~kg} / \mathrm{m}^{3}$; bulk rock density $2.6 \mathrm{~g} / \mathrm{cm}^{3}$ is adopted as carbonate source rock density value; normal temperature in the study area is considered as $20^{\circ} \mathrm{C}$. 
As mentioned above, there are many characteristics in source rock, including source rock lithology, mineral constituent, specific surface area and TOC which is only one of the factors that control residual oil hydrocarbon amount (Tissot and Welte 1984). In order to serviceably describe the retention characteristics of source rocks in the study area, $f(C)$ is set to characterize the residual capacity of source rocks with different TOC, and $A_{0}, A_{1}$ and $A_{2}$ are empirical constants in study areas related to $f(C)$. They are calculated by simulation and statistical analysis of actual residual hydrocarbon amount in source rocks. A total of 56 data from typical source rocks interval were selected to calculate and determine $A_{0}, A_{1}$ and $A_{2}$ in the study area. The typical source rock data were confirmed that massive hydrocarbon expulsion has occurred ( $\mathrm{Li}$ et al. 2015). The 56 data are from PetroChina Tarim Oilfield Company. According to the binomial (Fig. 3i), $A_{0}=0.026, A_{1}=-0.057, A_{2}=0.024$ can be determined for Eq. (4). $D$ refers to variance of the 56 TOC data, and $D=0.0163$ is determined for Eq. (3). $R$ ' is the general hydrocarbon expulsion threshold of the source rocks in Tarim Basin, and $R^{\prime}=0.95 \%$ is determined for Eq. (3) (Pang et al. 2012).
The source rock properties (organic matter abundance, organic matter type, organic matter maturity, mineral components and specific surface areas) also control the amount of absorbed gas (Dubinin 1960). Parameter $K(C)$ is set to describe the absorbtion ability of source rocks with different organic carbon abundances, and $B_{0}$ and $B_{1}$ are related coefficients for the linear relationship between absorbtion ability of source rocks and TOC in the study area. A total of 14 data from typical source rocks interval were selected to determine $B_{0}$ and $B_{1}$. The typical source rock interval was the one confirmed that a large amount of hydrocarbon expulsion have occurred. The data were from adsorption experimental results by the Tarim Oilfield Company, PetroChina. According to the relationship, $B_{0}=0.324$ and $B_{1}=0.730$ can be obtained (Fig. 3j), respectively.

\subsection{Calculation results of hydrocarbon amount at expulsion threshold}

All parameters and coefficients obtained above were substituted in each calculation model, through which the hydrocarbon amount at expulsion threshold was determined for
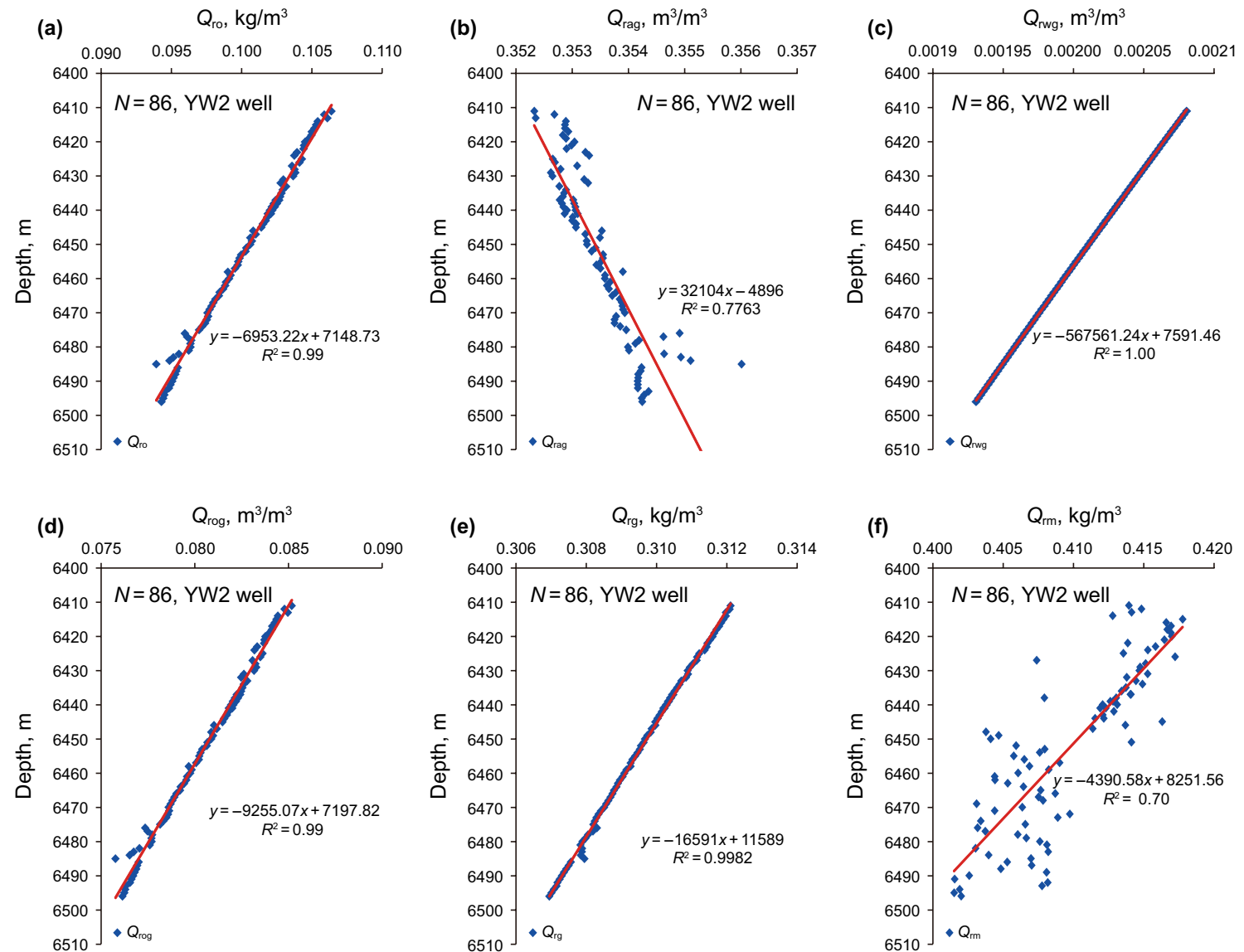

Fig. 4 Relationship of residual hydrocarbon amount and depth of YW2 well, Tarim Basin. a Liquid hydrocarbon amount; b absorbed gas amount; $\mathbf{c}$ water-soluble gas amount; $\mathbf{d}$ oil-soluble hydrocarbon amount; $\mathbf{e}$ gaseous hydrocarbon amount; $\mathbf{f}$ total hydrocarbon amount 
the case study of YW2 well. Results indicate that hydrocarbon amounts at expulsion threshold of liquid, and gas soluble in oil and water, decrease linearly with increasing depths (Fig. 4a, c, d), while gas adsorption in rocks increases with depth (Fig. 4b). However, in general, the total gaseous hydrocarbons and the total hydrocarbons at expulsion threshold decrease linearly with increasing burial depth (Fig. 4e, f). The hydrocarbon amount at expulsion threshold based on modeled parameter values and actual TOC data varies from $0.402 \mathrm{~kg} / \mathrm{m}^{3}$ to $0.418 \mathrm{~kg} / \mathrm{m}^{3}$, with a mean value of $0.410 \mathrm{~kg} /$ $\mathrm{m}^{3}$, among which the absorbed gas amounts from $0.352 \mathrm{~m}^{3} /$ $\mathrm{m}^{3}$ to $0.356 \mathrm{~m}^{3} / \mathrm{m}^{3}$, the water-soluble gas amounts from $0.0019 \mathrm{~m}^{3} / \mathrm{m}^{3}$ to $0.0021 \mathrm{~m}^{3} / \mathrm{m}^{3}$, the oil-soluble gas amounts from $0.076 \mathrm{~m}^{3} / \mathrm{m}^{3}$ to $0.082 \mathrm{~m}^{3} / \mathrm{m}^{3}$, and the oil amounts from $0.064 \mathrm{~kg}^{3} / \mathrm{m}^{3}$ to $0.106 \mathrm{~kg} / \mathrm{m}^{3}$ (Table 3 ).

\subsection{Calculation results of actual residual hydrocarbon amount}

Actual residual hydrocarbon amount in Middle-Upper Ordovician source rocks in YW2 well can be estimated by using these parameters and Rock-Eval pyrolysis data $\left(S_{1}\right)$ (Fig. 5), and the amount lies between $0.034 \mathrm{~kg} / \mathrm{m}^{3}$ and $2.953 \mathrm{~kg} / \mathrm{m}^{3}$ (Table 3).

\subsection{Identification results of effective source rocks}

Based on the above method and calculation results, it can be determined whether hydrocarbon expulsion has occurred in Middle-Upper Ordovician interval of YW2 well. Results indicate that hydrocarbon expulsion took place in carbonate source rocks which have a low value of $\mathrm{TOC}_{\mathrm{pd}}$ in the Yijianfang formation between $6452 \mathrm{~m}$ and $6487 \mathrm{~m}$ (Fig. 6).

\section{Discussion}

Early in 1933, Trask pointed out the hydrocarbon generation capacity of carbonate rocks. In the following decades, people gradually began to pay attention to carbonate rock series and carried out a series of targeted research work. The studies effectively guided oil and gas exploration, and a number of large and medium oil and gas fields contributed by carbonate source rocks were successfully discovered. For example, the Paleozoic strata in the Williston Basin are almost composed of limestone, dolomite and evaporate, with very few argillaceous rocks. Its oil and gas mainly come from the Red River, Winnipegosis, Bakken and Lodgepole Formation of the Upper Ordovician-Lower Carboniferous (Tao et al. 2013). The organic geochemical indexes of oils in the Tahe Oilfield in the Tarim Basin show the ratio of $\mathrm{C}_{29}$ hopane/ $\mathrm{C}_{30}$ hopane over 0.6 and $\mathrm{C}_{35} S$ hopane $/ \mathrm{C}_{34} S$ hopane over 0.8 , indicating obvious characteristics of derived from carbonate source rocks (Liu et al. 2017). This is consistent with the study results by Peters and Moldowan (1993) on the oil characteristics from marine carbonate source rocks.

Compared with mudstone, the threshold of TOC value as an effective source rock of carbonate rock is generally smaller. On the one hand, the adsorption and retention capacities of carbonates are weaker than clays (Tissot and Welte 1984), resulting in a less minimum generation amount to expel hydrocarbons. Pyrolysis experiments also clearly manifested that clay-rich rocks can retain a significantly greater quantity of hydrocarbons than carbonate source rocks (Katz 1983). On the other hand, different from marl source rocks, bioprecursors of carbonate source rocks are mainly plankton assemblages (Liu et al. 2017) with high hydrocarbon transformation ratio, resulting in low presentday TOC values remaining in the source rocks. Type I and Type II kerogens (regardless of the weight of TOC, their hydrocarbon yield are significantly higher) are, in general, more easily found in carbonates than in siliciclastic facies (Hunt 1967). Additionally, different from mudstones, the mineral constituent of carbonate source rocks has specialty that during geological process, hydrocarbons, aqueous carboxylic acids and carbon dioxide produced by hydrolytic disproportionation may reach a state of invertible metastable thermos dynamic equilibrium, including sedimentary minerals such as calcite (Helgeson et al. 1993; Jeffrey 2003), forming carboxylate salts with the structure compatible in carbonate minerals and then preserved in the carbonate source rocks. These carboxylate salts widely distributed in marine carbonate source rocks, keep stable in low temperature and have certain hydrocarbon generation capability at high evolution stage (Carothers and Kharaka 1978; Vandegrift and Horwitz 1980; Liu et al. 2017). Since during our traditional TOC values tests inorganic carbon contents are removed by dripping diluted hydrochloric acid, the organic carbon contents of carboxylate salts would be easy to lose leading to the underestimate of TOC values and hydrocarbon generation potential at high evolution stage (Liu et al. 2016). However, the loss of organic carbon affects more lightly to the TOC test of muddy source rocks, since the contents of acid-soluble carbonate minerals of them are low and the partial acidic environment where muddy source rock formed is not beneficial for the formulation of carboxylate salts (Liu et al. 2017).

\subsection{Hydrocarbons self-generated and retained in samples}

Due to the particularity of lithology, carbonate rocks can act as source rocks to provide hydrocarbons as well as reservoir rocks to provide storage for hydrocarbon accumulation (Trask 1933; Li et al. 1998; Wang et al. 2016; Liu et al. 2017). Therefore, it is essential to ensure the hydrocarbons 
Table 2 Summary table of definitions of the variables

\begin{tabular}{|c|c|c|}
\hline Variable & Definition & Unit \\
\hline$Q_{\mathrm{r}}$ & The actual residual hydrocarbons amount & $\mathrm{kg} / \mathrm{m}^{3}$ \\
\hline$Q_{\mathrm{rm}}$ & The quantity of hydrocarbon in a single unit volume of source rock at expulsion threshold & $\mathrm{kg} / \mathrm{m}^{3}$ \\
\hline$Q_{\text {ro }}$ & The quantity of liquid residual hydrocarbon in a single unit volume of rock at expulsion threshold & $\mathrm{kg} / \mathrm{m}^{3}$ \\
\hline$Q_{\text {rag }}$ & The quantity of absorbed gas in a single unit volume & $\mathrm{kg} / \mathrm{m}^{3}$ \\
\hline$Q_{\text {rwg }}$ & The quantity of water-soluble gas in a single unit volume & $\mathrm{kg} / \mathrm{m}^{3}$ \\
\hline$Q_{\text {rog }}$ & The quantity of oil-soluble gas in a single unit volume & $\mathrm{kg} / \mathrm{m}^{3}$ \\
\hline$Q_{\text {rai }}$ & The quantity of residual absorbed hydrocarbon component $i$ in a signal unit volume of rock & $\mathrm{m}^{3} / \mathrm{m}^{3}$ \\
\hline$Q_{\text {rwgi }}$ & Water-soluble hydrocarbon component $i$ in pore water & $\mathrm{m}^{3} / \mathrm{m}^{3}$ \\
\hline$Q_{\text {rogi }}$ & The quantity of oil-soluble hydrocarbons component $i$ in pore oil & $\mathrm{m}^{3} / \mathrm{m}^{3}$ \\
\hline$i$ & The $i$ th component of gaseous hydrocarbons such as $\mathrm{CH}_{4}, \mathrm{C}_{2} \mathrm{H}_{6}, \mathrm{C}_{3} \mathrm{H}_{8}$ and $\mathrm{C}_{4} \mathrm{H}_{10}$ & \\
\hline$\varphi$ & Source rock porosity & $\%$ \\
\hline$\varphi_{\mathrm{n}}$ & Porosity in normal compaction state & $\%$ \\
\hline$\Delta \varphi$ & Residual porosity in under compacted state & $\%$ \\
\hline$S_{\mathrm{o}}$ & Fluid residual hydrocarbon flow saturation in source rock & $\%$ \\
\hline$S_{\text {om }}$ & Saturation of liquid residual hydrocarbon in source rock & $\%$ \\
\hline$f(C)$ & Correlation factor of organic matter abundance and liquid residual hydrocarbon amount in source rock & \\
\hline$B_{\mathrm{k}}$ & The proportion of light hydrocarbons in liquid hydrocarbons & $\%$ \\
\hline$C$ & Organic matter content & $\%$ \\
\hline$R_{\mathrm{o}}$ & Vitrinite reflectance & $\%$ \\
\hline$\rho_{\mathrm{o}}$ & Density of liquid residual hydrocarbons & $\mathrm{kg} / \mathrm{m}^{3}$ \\
\hline$\rho_{\mathrm{r}}$ & Density of source rocks & $\mathrm{kg} / \mathrm{m}^{3}$ \\
\hline$\rho_{\mathrm{g}}$ & Density of gaseous hydrocarbons & $\mathrm{kg} / \mathrm{m}^{3}$ \\
\hline$A_{0}, A_{1}, A_{2}, D$ and $R^{\prime}$ & Constants concerning the characteristics of the source rocks in the study area & \\
\hline$n$ & Correlation factor related to pressure & \\
\hline$T$ & Formation temperature & ${ }^{\circ} \mathrm{C}$ \\
\hline$P$ & Formation pressure & $\mathrm{Pa}$ or $\mathrm{MPa}$ \\
\hline$K_{\mathrm{w}}$ & Wettability & \\
\hline$K(C)$ & Correlation factor between organic matter abundance and absorbed gas amount in source rock & \\
\hline$K\left(R_{\mathrm{o}}\right)$ & Correlation factor between thermal maturity and absorbed gas amount in source rock & \\
\hline$K(i)$ & Proportion of component $i$ of gaseous hydrocarbons dissolved in liquid hydrocarbons & \\
\hline$K\left(\rho_{\mathrm{o}}\right)$ & Calibration factor reflecting variation of oil-soluble gaseous hydrocarbons with oil density, as an integer & \\
\hline$K_{i}$ & Correlation factor between hydrocarbon component and absorbed gas amount in source rock & \\
\hline$B_{0} B_{1}$ & $\begin{array}{l}\text { Related coefficient for the relationship between absorbtion ability of source rocks and organic carbon } \\
\text { content }\end{array}$ & \\
\hline$X_{K}$ & Salinity of formation water & $\mathrm{g} / \mathrm{L}$ \\
\hline$q_{\mathrm{w}}(i)$ & Soluble gaseous hydrocarbon component $i$ amount in formation water & $\mathrm{m}^{3} / \mathrm{m}^{3}$ \\
\hline$q_{\mathrm{w}}(1, T, P)$ & $\begin{array}{l}\text { Solubility of gaseous hydrocarbon component } i \text { in pore water controlled by pressure, temperature and } \\
\text { water salinity }\end{array}$ & \\
\hline$q_{\mathrm{w}}\left(1, T, P, X_{K}\right)$ & Variance of methane solubility in water controlled by pressure, temperature and water salinity & \\
\hline$q_{\mathrm{o}}(i)$ & Quantity of gaseous hydrocarbons component $i$ dissolved in liquid hydrocarbons & $\mathrm{m}^{3} / \mathrm{m}^{3}$ \\
\hline$q_{\mathrm{og}}(T, P)$ & $\begin{array}{l}\text { The gaseous hydrocarbon in liquid hydrocarbons, an empirical function of temperature and pressure condi- } \\
\text { tions }\end{array}$ & $\mathrm{m}^{3} / \mathrm{m}^{3}$ \\
\hline$S_{1+}$ & Actual residual liquid hydrocarbon amount considering light hydrocarbons & $\mathrm{mg} / \mathrm{g}$ \\
\hline$S_{1}$ & Free volatile hydrocarbons thermally flushed from a rock sample at $300{ }^{\circ} \mathrm{C}$ & $\mathrm{mg} / \mathrm{g}$ \\
\hline$S_{2}$ & Products that crack during standard Rock-Eval pyrolysis temperatures $\left(300-650{ }^{\circ} \mathrm{C}\right)$ & $\mathrm{mg} \mathrm{HC/g}$ rock \\
\hline$H$ & Depth & $\mathrm{m}$ \\
\hline$T_{\max }$ & The highest pyrolysis temperature & ${ }^{\circ} \mathrm{C}$ \\
\hline TOC & Total organic carbon & $\mathrm{wt} \%$ \\
\hline $\mathrm{TOC}_{\mathrm{o}}$ & Initial TOC content & $\mathrm{wt} \%$ \\
\hline $\mathrm{TOC}_{\mathrm{pd}}$ & Present-day TOC & $\mathrm{wt} \%$ \\
\hline
\end{tabular}


Table 2 (continued)

\begin{tabular}{lll}
\hline Variable & Definition & Unit \\
\hline $\mathrm{VR}_{\mathrm{E}}$ & Vitrinite equivalent & $\%$ \\
\hline
\end{tabular}

(a)

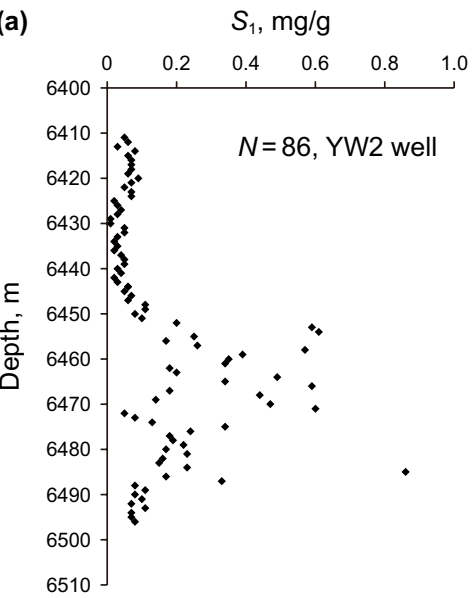

(b)

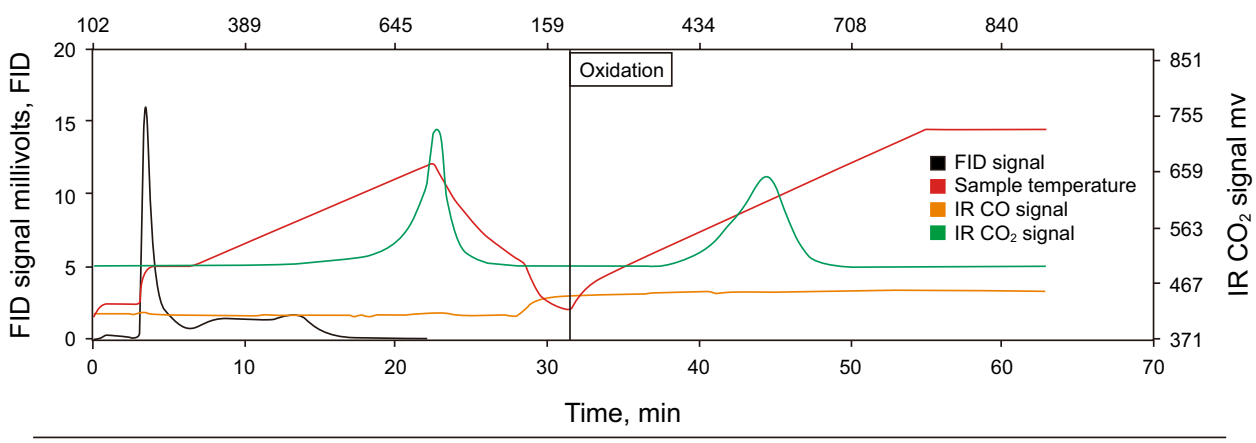

\begin{tabular}{cccccccc}
\hline Well & Sample & Depth, $\mathrm{m}$ & Weight, $\mathrm{mg}$ & $\mathrm{S}_{1}, \mathrm{mg} / \mathrm{g}$ & $\mathrm{S}_{2}, \mathrm{mg} / \mathrm{g}$ & $\mathrm{TOC}, \%$ & $T_{\max },{ }^{\circ} \mathrm{C}$ \\
\hline YW2 & $\mathrm{C}-625221$ & 6454 & 71.0 & 0.58 & 0.52 & 0.275 & 462
\end{tabular}

(c)

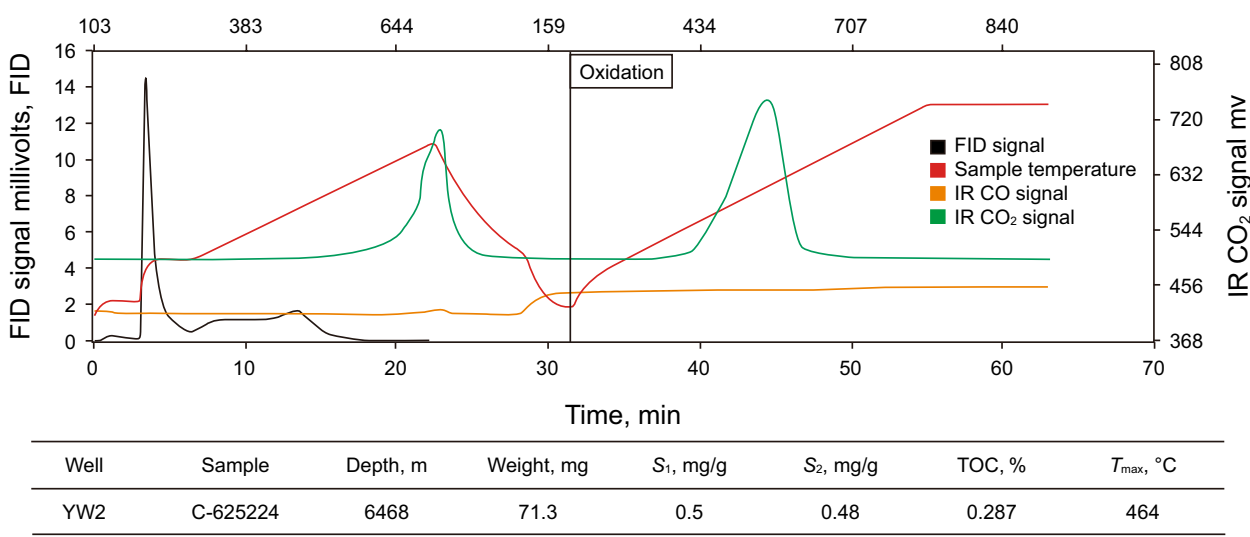

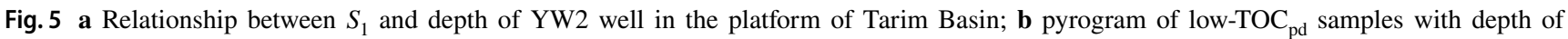
$6454 \mathrm{~m}$; and $\mathbf{c}$ pyrogram of low-TOC ${ }_{\mathrm{pd}}$ samples with depth of $6468 \mathrm{~m}$ from the Middle-Upper Ordovician Formation in the YW2 well, Tarim Basin 


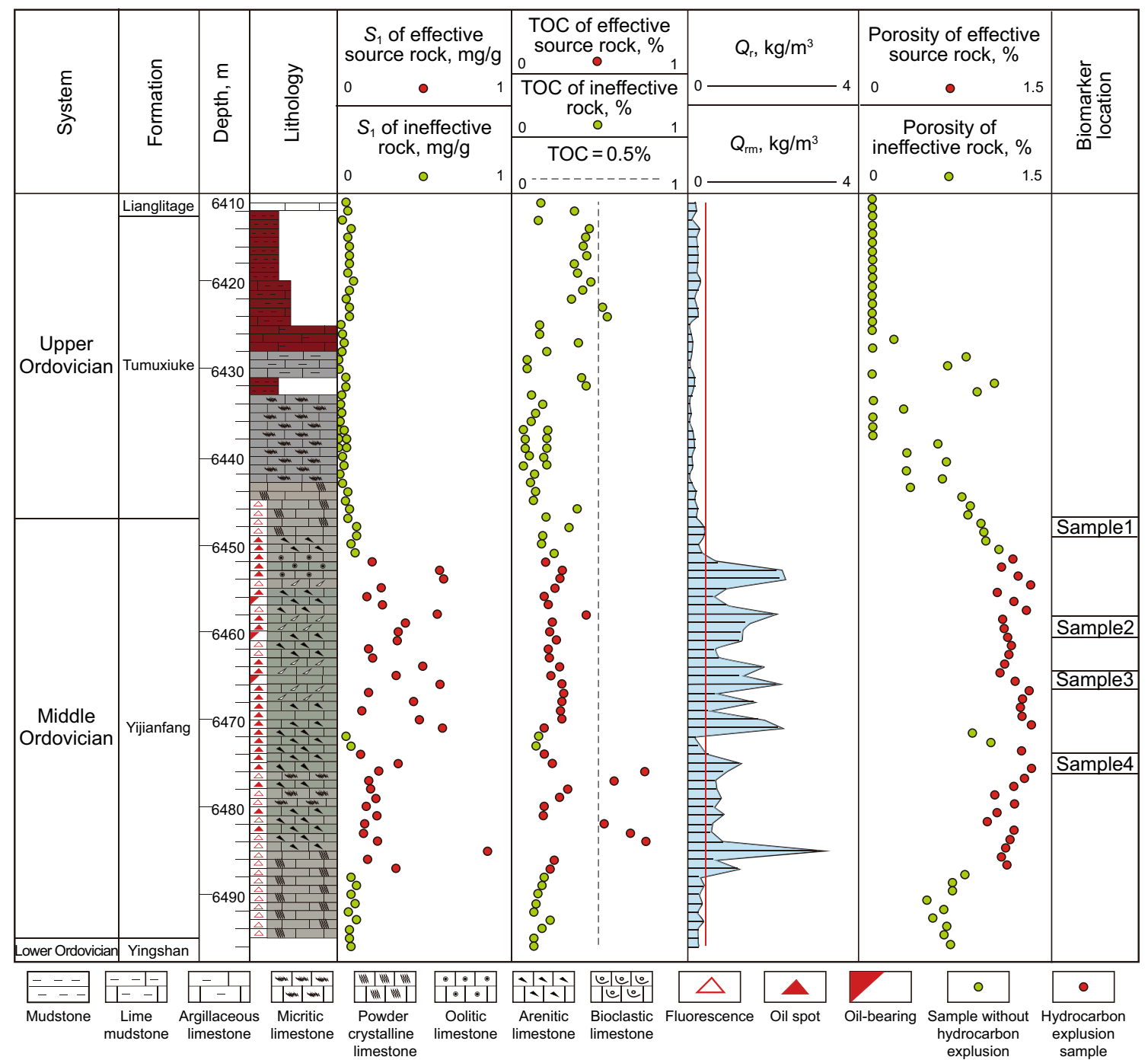

Fig. 6 Distinguish results of effective and ineffective source rocks of Ordovician in YW2 well
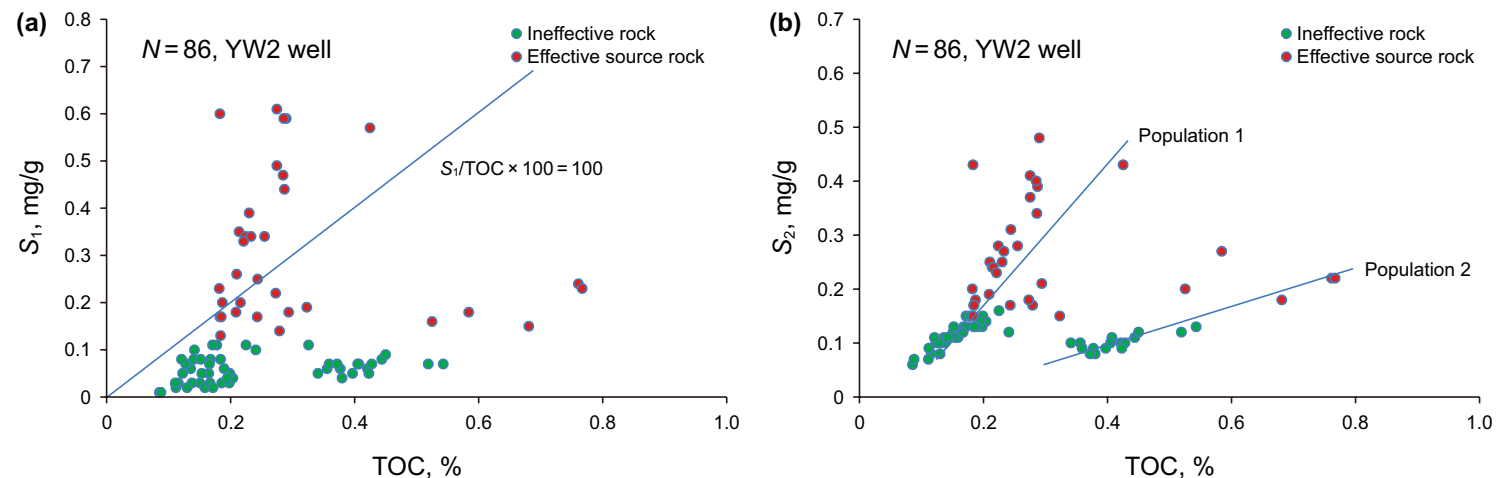

Fig. $7 S_{1}$ and $S_{2}$ characteristics of effective source rocks and ineffective rocks with TOC of YW2 well, Tarim Basin. a $S_{1}$ vs TOC; b $S_{2}$ vs TOC 
are self-generated and retained and exclude those charged from other source rocks when identifying the effectiveness of low-TOC abundance source rocks.

Several evidences can be obtained to prove the hydrocarbons in samples of YW2 well are self-generated and retained. Firstly, according to the Rock-Eval pyrolysis experiment results, the effective source rocks with low-TOC ${ }_{\mathrm{pd}}$ generally have characteristics with $S_{1} /$ TOC $\times 100 \geq 100 \mathrm{mg} / \mathrm{g}$ TOC, HI $\left(S_{2} / \mathrm{TOC} \times 100\right) \geq 50 \mathrm{mg} / \mathrm{g}$, and extremely low porosity (Figs. 6 and 7). The relatively high $S_{1} /$ TOC values suggest that the actual amount of residual hydrocarbons is relatively large (Fig. 7a) so that the kerogens can generate sufficient hydrocarbons to result in enough dynamic force to against the capillary resistance and expel outward to be referred as effective source rocks. On the other hand, the relatively high value of $\mathrm{HI}(>50 \mathrm{mg} / \mathrm{g})$ shows the fact that the kerogen in the source rocks can continue to generate and expel hydrocarbons (Fig. 7b).

Secondly, reservoir porosity in effective source rock interval is much higher than those in the non-source rock interval. It may be due to the organic porosity present in the effective source rock by hydrocarbon generation and expulsion (Modica and Lapierre 2012; Chen and Jiang 2016). According to the logging data of the study interval, the porosity is poor developed, which ranges from $0.10 \%$ to $1.34 \%$ (Fig. 6). Based on the organic porosity calculation model (Chen and Jiang 2016), the average of estimated organic porosity reaches $1.2 \%$, which is accordant to the porosity contrasts of two types of carbonates in YW2 well. In the process of tight oil charging, it is always influenced by capillary pressure, viscous force and inertial force (Zou et al. 2013). Effective reservoirs depict a lower porosity limit within which the oils can accumulate (Jiang et al. 2017). In Tarim Basin, the effective carbonate reservoirs generally have porosity greater than $1.8 \%$ (Pang et al. 2013). Additionally, the well is located in the slope adjacent to the depression lack of faults and is developed low permeability (Fig. 1). Thus, the studied interval cannot be regarded as effective reservoir rocks for migrated oils.

\subsection{Oil-source correlation}

Hydrocarbon expulsion has been identified from the potential carbonate source rocks in Middle-Upper Ordovician in Tarim Basin. Oils from the Middle-Upper Ordovician source rocks have features including a relatively low amount of gammacerane, 24-isopropylcholestanes, $\mathrm{C}_{35}$ homohopanes, 24-norcholestanes, $\mathrm{C}_{28}$ regular steranes and $\mathrm{C}_{30}$ dinosteranes (4 $\alpha, 23,24$-trimethylcholestanes) yield a $\mathrm{V}$-shaped regular sterane distribution (Zhang et al. 2000, 2002a, 2004; Wang and Xiao 2004; Li et al. 2015; Huang et al. 2016).

Based on the characteristics of biomarkers, an oil-source correlation was performed between the crude oil samples from discovered oil accumulations and potential effective carbonate source rocks. Results suggest that there are many similar characteristics between potential effective low-TOC
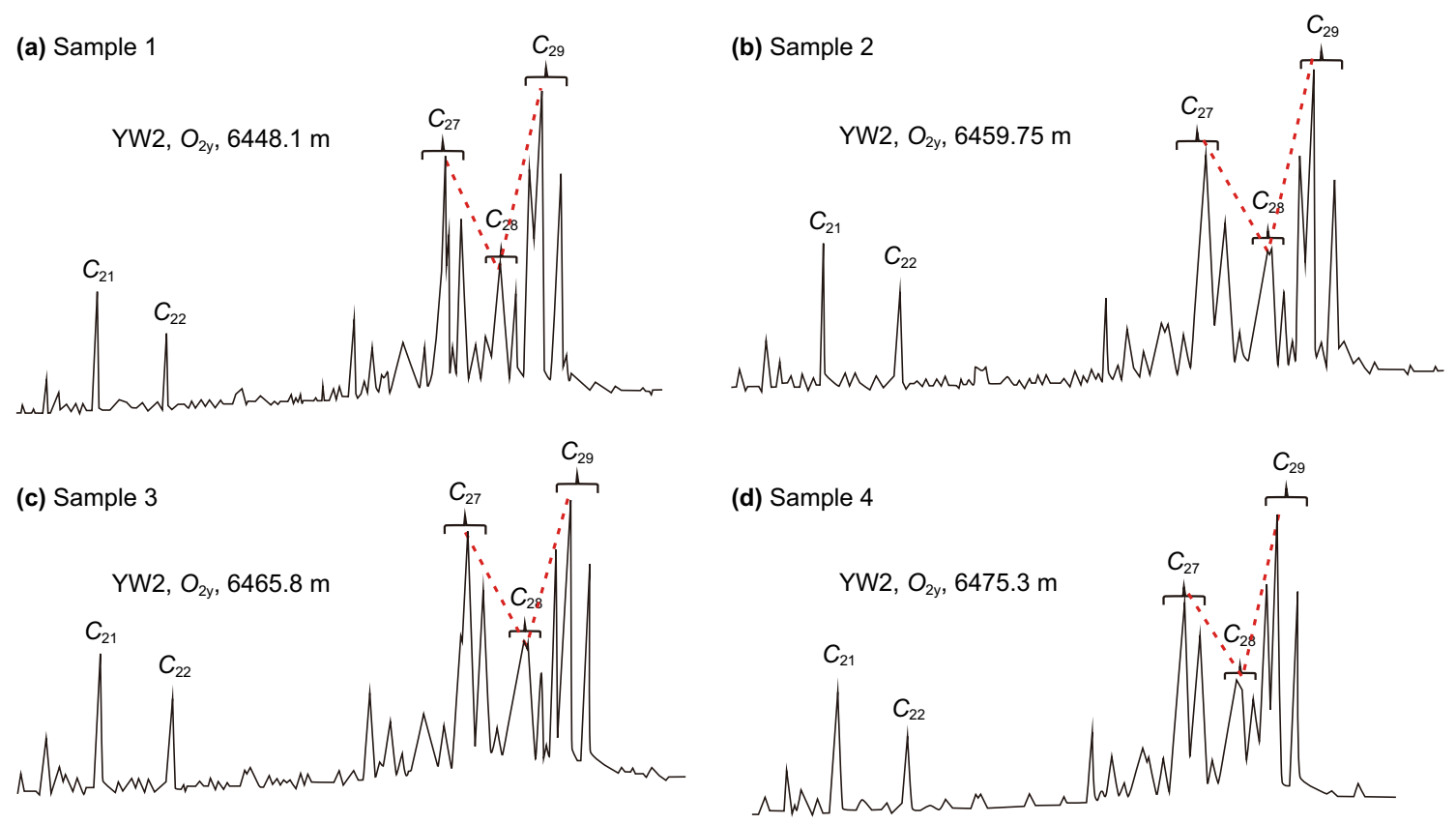

Fig. 8 Regular sterane characteristics of Upper-Middle Ordovician source rocks with hydrocarbon expulsion in YW2 well, Tarim Basin $(m / z=217)$ (Sample locations are shown in Fig. 6) 


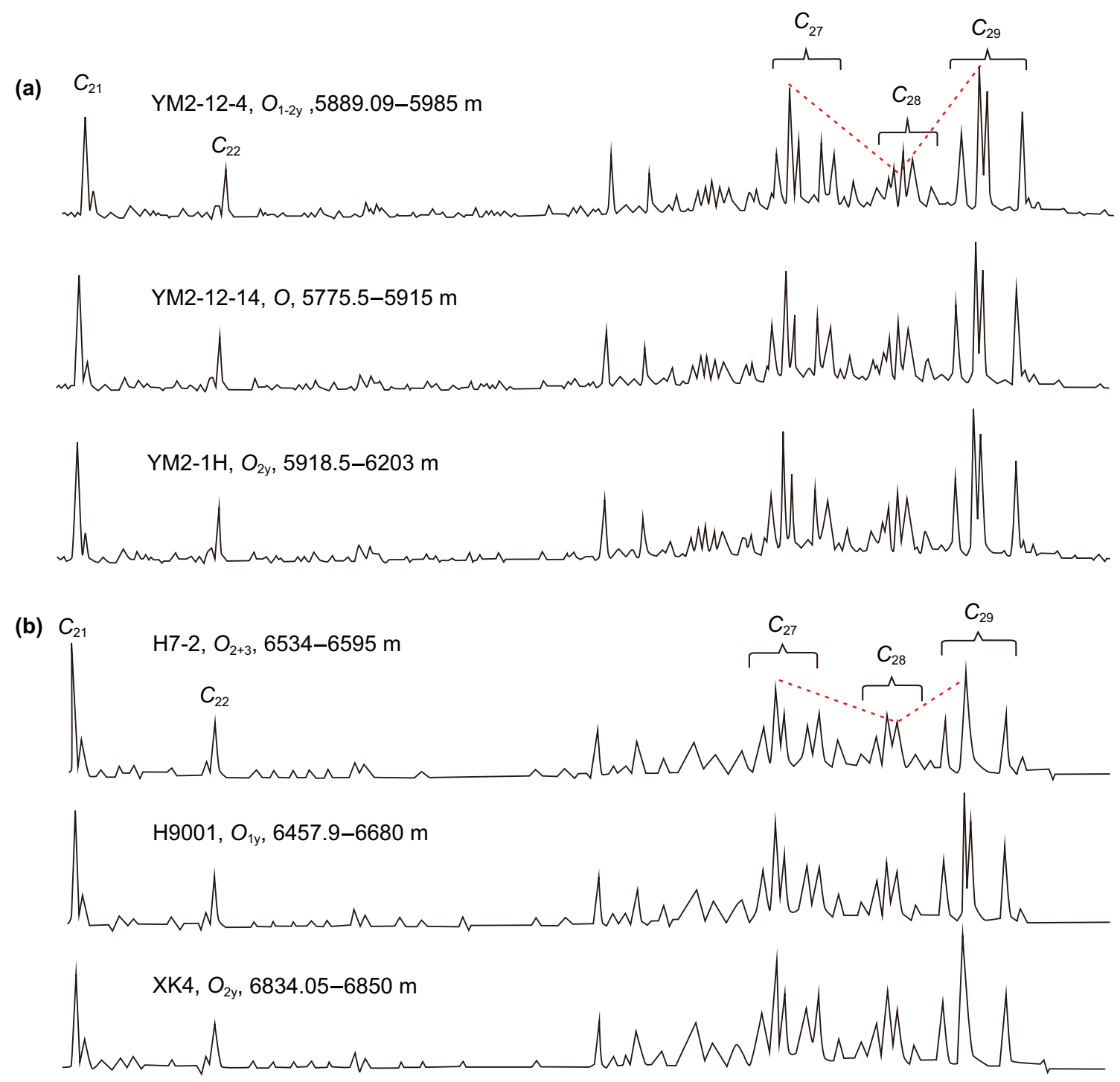

Fig. 9 Oil regular sterane distribution characteristics of Ordovician in Tabei area, Tarim Basin $(m / z=217$, and well locations are shown in Fig. 1a). a Crude oil from Yingmaili oilfield; $\mathbf{b}$ crude oil from Halahatang oilfield

source rocks in well YW2 and crude oils in the Yingmaili and Halahatang oilfields in the Tabei area, including low $\mathrm{C}_{28}$ regular steranes and a ' $\mathrm{V}$ '-shaped trend of sterane distribution $\left(\mathrm{C}_{27}, \mathrm{C}_{28}\right.$ and $\mathrm{C}_{29}$ regular steranes) (Figs. 8 and 9), which indicate that crude oils may be originated from the effective source rocks with low-TOC abundance in the Tabei area.

\subsection{Method verification}

Fifteen samples from typical source rock wells, including KN1, TD1 and TD2 wells (locations are shown in Fig. 1, Li et al. 2010), were used to verify the above model. Based on the method and model, critical and actual residual hydrocarbon amounts were calculated. As results indicate, actual residual hydrocarbon amounts of mature source rock intervals that have expelled hydrocarbons are always greater than or equal to critical hydrocarbon amount at expulsion threshold (Fig. 10a).

Furthermore, 43 rock samples were also selected from typical non-source rock (that cannot expel hydrocarbon) intervals of TC1 and TZ10 wells in Tarim Basin (locations are shown in Fig. 1), to compute residual hydrocarbon amounts based on the above-mentioned method and model. Results indicate that of non-source rock interval samples incapable of hydrocarbon expulsion, actual residual hydrocarbon amount is $100 \%$ less than critical amount at expulsion threshold (Fig. 10b).

Verification results indicate that the proposed method and models are useful to identify effective source rocks which 

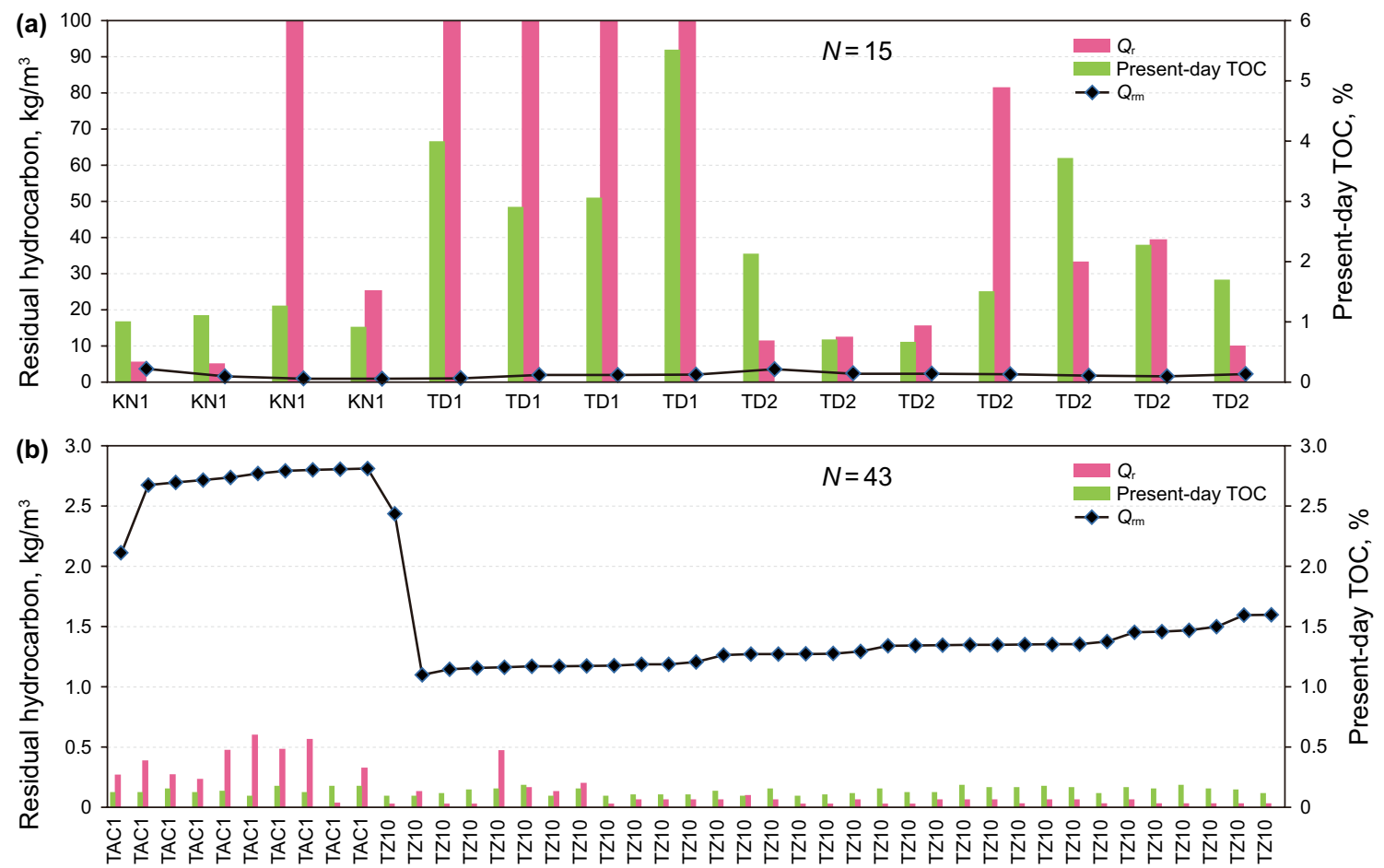

Fig. 10 Relationship between actual and residual hydrocarbon at expulsion threshold amounts of confirmed typical source rocks and non-source intervals, Tarim Basin. a Typical source rocks (well locations are shown in Fig. 1a); b non-source rocks (well locations are shown in Fig. 1a)

have expelled hydrocarbons from non-source rocks and can thus be applied in the identification of effective low organic matter abundance source rock in carbonate successions.

The method proposed in this study takes mass balance principle as basis, by determining and comparing the hydrocarbon expulsion threshold and actual residual hydrocarbon amount, to identify the samples reaching expulsion threshold as effective source rocks. Compared with traditional methods to identify effective source rocks using the present-day TOC values, the proposed method is an innovation. It eliminates the influence of present-day TOC values changing in different evolution stages. The evaluation method may be more objective, especially for the source rocks at high evolution stage, such as those in the Tarim Basin and Sichuan Basin in China. Currently, lacustrine carbonate source rocks have also been noted during recent years (Liu et al. 2019). For example, the carbonate source rocks might have act as important oil contributors in the lacustrine Mahu sag (Cao et al. 2019). Although the study case in this study is for marine carbonate rocks, based on the principle and methods of mass balance, the identification of effective lacustrine carbonate rocks is also applicable.

The limitation of the method, as described in methodology section, involves many parameters, such as
Rock-Eval data, reservoir volumetric parameters, oil density, water salinity, formation pressure and temperature. This requires the data of the application area is relatively sufficient. Meanwhile, during the process of determining actual residual hydrocarbon amount, we need to identify whether the residual hydrocarbons in the sample are migrated or self-generated. This part is quite essential and needs multiple means to comprehensively identify so as to eliminate the influence of migrated hydrocarbons. In addition to the methods discussed in Sect. 4.1 in this study, Loucks and Reeds (2014) as well as Li et al. (2018) provided effective methods to identify migrated hydrocarbons.

\subsection{High original TOC and original hydrogen index of effective $T O C_{p d}$ rocks}

In this study, the interval depth for samples is $86 \mathrm{~m}$ and the value of $\mathrm{VR}_{\mathrm{E}}(1.31 \%-1.41 \%)$ is similar; hence, $\mathrm{HI}$ at present day can be used to differentiate diverse populations of organic matter. Closer examination suggests the presence of two distinct organic matter populations within YW2 samples: one population with $\mathrm{HI}>50 \mathrm{mg} / \mathrm{g}$ and the other with $\mathrm{HI}<50 \mathrm{mg} / \mathrm{g}$ (Fig. 7b). Utilizing the method proposed by Chen and Jiang (2015) on kerogen kinetics, the original 
Table 3 Calculation results of hydrocarbon amount at expulsion threshold and actual residual hydrocarbon amount of Middle-Upper Ordovician Formation in YW2 well in the platform of Tarim Basin

\begin{tabular}{llll}
\hline Amount & Minimum & Average & Maximum \\
\hline$Q_{\text {rag }}, \mathrm{m}^{3} / \mathrm{m}^{3}$ & 0.352 & 0.353 & 0.356 \\
$Q_{\mathrm{rwg}}, \mathrm{m}^{3} / \mathrm{m}^{3}$ & 0.00190 & 0.00200 & 0.00210 \\
$Q_{\mathrm{rog}}, \mathrm{m}^{3} / \mathrm{m}^{3}$ & 0.0760 & 0.0800 & 0.0820 \\
$Q_{\mathrm{ro}}, \mathrm{kg} / \mathrm{m}^{3}$ & 0.0640 & 0.0970 & 0.106 \\
$Q_{\mathrm{rm}}, \mathrm{kg} / \mathrm{m}^{3}$ & 0.402 & 0.410 & 0.418 \\
$Q_{\mathrm{r}}, \mathrm{kg} / \mathrm{m}^{3}$ & 0.0340 & 0.554 & 2.953 \\
\hline
\end{tabular}

hydrogen index $\left(\mathrm{HI}_{0}\right)$ of the above two populations is estimated and the kerogen types of them are further identified according to the values of $\mathrm{HI}_{0}$. Results show that the $\mathrm{HI}_{0}$ values of population 1 and 2 are $870 \mathrm{mg} / \mathrm{g}$ and $440 \mathrm{mg} / \mathrm{g}$, respectively. The kerogens of population 1 are identified of Type I and that of population 2 is of Type II. The components statistical data of optical kerogen organic macerals in well YW2 clarify the fact that there are kerogens from pelagic algae with $\geq 80 \%$ of sapropelinite and kerogens from benthic algae with $\geq 20 \%$ of provitrinite (similar with vitrinite) (Table 4).

The effective low-TOC carbonate source rocks are all with type I kerogen (Fig. 7b). We use the method proposed by Chen and Jiang (2016) to estimate the initial TOC content of effective low-TOC source rock. The TOC recovery coefficient $\left(\mathrm{TOC}_{\mathrm{o}} / \mathrm{TOC}\right.$ ) ranges from 2.5 to 3.3 with an average of 2.9. When present-day TOC is $0.5 \%$, the $\mathrm{TOC}_{\mathrm{o}}$ can reach about $1.5 \%$. The result is consistent with that by Pang et al. (2014). When source rock reaches mature stage, both sufficient organic matter (quantity) and good kerogen type (quality) play crucial roles in hydrocarbon generation and expulsion. Figure 7 also shows when TOC is less than $0.5 \%$ in carbonate succession, there are two types of carbonates for ineffective source rocks. One is that poor type of kerogen to generate any significant amount of oil; the second is that although kerogens with good types, low TOC in them could not generate sufficient hydrocarbons amount to meet the required threshold.

\subsection{Probable contribution of low-TOC $C_{\mathrm{pd}}$ source rock to hydrocarbon resources}

Previous controversy on the source of marine oils in Tarim Basin's platform concentrated on different opinions from the views of geochemistry and geology. Based on the previous studies on geochemical biomarkers parameters and carbon isotope characteristics, it is reported that the marine hydrocarbons mainly come from Middle-Upper Ordovician source rocks (Zhang et al. 2000, 2002b, 2004, 2007; Wang and Xiao 2004; Zhao et al. 2008; Li et al. 2008; Wang et al. 2014). However, recent data indicate that the organic matter contents of carbonate rocks in the Middle-Upper Ordovician are commonly developed low for the oil/gas accumulations in the basin (Fig. 1). Therefore, the Cambrian-Lower source rocks with high present-day organic matter abundance are regarded as the main source for widespread distribution of hydrocarbon accumulations in the carbonate platform successions in the basin (Pang et al. 2016). Nevertheless, according to the third round of National resource assessment that was based on contribution of high abundance Cambrian source rocks, the predicted in place resources of oil, gas and oil equivalent in Tazhong area, is $0.947 \times 10^{9}$ tons, $473.2 \times 10^{9} \mathrm{~m}^{3}$ and $1.324 \times 10^{8}$ tons, respectively. However, the $3 \mathrm{P}$ reserves of natural gas and total oil equivalent alone are $594.3 \times 10^{9} \mathrm{~m}^{3}$ and $1.041 \times 10^{9}$ tons at present (Yang 2012), more than or close to total resources of the assessment. Similarly, in Tabei area, the oil, gas and oil equivalent resources are $1.816 \times 10^{9}$ tons, $820.4 \times 10^{9} \mathrm{~m}^{3}$ and $2.47 \times 10^{9}$ tons, respectively, while the present $3 \mathrm{P}$ reserve of oil has been higher than $3.0 \times 10^{9}$ tons (Yang 2012), implying the presence of additional source rocks.

Employing the method of hydrocarbon generation and expulsion, quantities of hydrocarbon expulsion from the Middle-Upper Ordovician effective carbonate source rocks with low-TOC $\mathrm{pd}_{\mathrm{p}}$ in Tazhong and Tabei areas had been preliminarily estimated (Pang et al. 2018). The expelled amount of hydrocarbons from the Middle-Upper Ordovician in Tarim Basin's platform was estimated to be $4.09 \times 10^{9}$ tons oil and $13.17 \times 10^{9}$ tons oil equivalent, respectively. If a proportion of $10 \%$ in the expelled hydrocarbons can be trapped and accumulated in carbonate platform successions in the

Table 4 Maceral compositions of kerogen in Ordovician of YW2 well

\begin{tabular}{lllllllc}
\hline Well & Formation & Depth $(\mathrm{m})$ & TOC $(\%)$ & $\begin{array}{l}\text { Sapropelinite group } \\
(\%)\end{array}$ & $\begin{array}{l}\text { Exinite group } \\
(\%)\end{array}$ & $\begin{array}{l}\text { Vitrinite-like group } \\
(\%)\end{array}$ & $\begin{array}{l}\text { Inert group } \\
(\%)\end{array}$ \\
\hline YW2 & $\mathrm{O}_{2} \mathrm{y}$ & 6448.1 & 0.326 & 70 & 3 & 21 & 6 \\
YW2 & $\mathrm{O}_{2} \mathrm{y}$ & 6459.75 & 0.230 & 78 & 1 & 20 & 1 \\
YW2 & $\mathrm{O}_{2} \mathrm{y}$ & 6465.8 & 0.224 & 80 & 0 & 14 & 6 \\
YW2 & $\mathrm{O}_{2} \mathrm{y}$ & 6468.7 & 0.287 & 80 & 4 & 16 & 0 \\
\hline
\end{tabular}


basin, combined with the resources of Cambrian-Lower carbonate source rocks considered in the third round of National resource assessment, the phenomenon that the estimated resource potentials lower than the $3 \mathrm{P}$ reserves can be explained. This provides insights for the longtime controversy between geologists and geochemists regarding the major source rocks contributing to hydrocarbon resources in carbonate platform in the basin. This also means that the effective low- $\mathrm{TOC}_{\mathrm{pd}}$ source rocks in Middle-Upper Ordovician succession can also be significant for the resource contribution of hydrocarbon accumulations in the basin.

\section{Conclusions}

1. The use of present-day TOC threshold as a sole criterion for determining effective source rock is arbitrary, especially for rocks with high maturity. The proposed method and models in this study evaluated and compared the hydrocarbon expulsion threshold and actual residual hydrocarbon amount and can be used to distinguish effective source rocks that have expelled hydrocarbons from the non-source rocks.

2. The free hydrocarbon retained in the potential source rock interval of the Middle-Upper Ordovician succession in YW2 Well lies between $0.034 \mathrm{~kg} / \mathrm{m}^{3}$ and $2.953 \mathrm{~kg} / \mathrm{m}^{3}$, and the calculated hydrocarbon expulsion threshold ranges from $0.402 \mathrm{~kg} / \mathrm{m}^{3}$ to $0.418 \mathrm{~kg} / \mathrm{m}^{3}$, suggesting that hydrocarbon expulsion took place in the Yijianfang Formation between $6452 \mathrm{~m}$ and $6487 \mathrm{~m}$ where the actual free hydrocarbon retained in the source rock surpasses the threshold value, such as the interval can be identified as effective carbonate source rocks though the $\mathrm{TOC}_{\mathrm{pd}}$ content in the interval is less than $0.5 \%$.

3. From the geochemical analysis, the effective carbonate source rocks display relatively higher values of $S_{1} /$ TOC and HI than those in the non-source rock intervals. Relative high porosity and much higher $S_{1} /$ TOC $(>1)$ than those in the non-source rock intervals, the effective source rock is potentially a self-sourced and selfretained unconventional reservoir system. The source rocks in Middle-Upper Ordovician Formation display similar features to that of crude oil discovered in Yingmaili oil field and Halahatang oil field in Tabei area, indicating that crude oil in Tabei area probably migrated from effective low-TOC carbonate source rocks.

4. Low-TOC $(\leq 0.5 \%)$ carbonates can be effective source rock with high original TOC and original hydrogen index during high mature stage. However, not all lowTOC carbonates are effective. The carbonates, either too low in TOC or too poor in quality of organic matter, cannot be an effective source rocks.

Acknowledgements This study was financially supported by the Science Foundation of China University of Petroleum, Beijing (Grant No. 2462020BJRC005) and the Joint Funds of National Natural Science Foundation of China (Grant No. U19B6003-02) . We appreciate the Tarim Oilfield Company, PetroChina, especially the Research Institute of Exploration and Development, for providing background geological data and permission to publish the results. We also thank the reviewers for their constructive comments and suggestions that improved the manuscript.

Open Access This article is licensed under a Creative Commons Attribution 4.0 International License, which permits use, sharing, adaptation, distribution and reproduction in any medium or format, as long as you give appropriate credit to the original author(s) and the source, provide a link to the Creative Commons licence, and indicate if changes were made. The images or other third party material in this article are included in the article's Creative Commons licence, unless indicated otherwise in a credit line to the material. If material is not included in the article's Creative Commons licence and your intended use is not permitted by statutory regulation or exceeds the permitted use, you will need to obtain permission directly from the copyright holder. To view a copy of this licence, visit http://creativecommons.org/licenses/by/4.0/.

\section{References}

Cao J, Xia LW, Wang TT, et al. An alkaline lake in the Late Paleozoic Ice Age (LPIA): a review and new insights into paleoenvironment and petroleum geology. Earth Sci Rev. 2019. https://doi. org/10.1016/j.earscirev.2020.103091.

Carothers WW, Kharaka YK. Aliphatic acid anions in oil-field waters: implications for origin of natural gas. AAPG Bull. 1978;62:244153. https://doi.org/10.1007/bf02634580.

Chen PJ. Comment on several topics in the geochemistry carbonate source rock. Pet Geol Exp.1985;7(1):3-12. https://doi. org/10.11781/sysydz198501003 (in Chinese).

Chen ZH, Jiang CQ. A data driven model for studying kerogen kinetics with application examples from Canadian sedimentary basins. Mar Pet Geol. 2015;67:795-803.https://doi.org/10.1016/j.marpe tgeo.2015.07.004.

Chen ZH, Jiang CQ. A revised method for organic porosity estimation in shale reservoirs using Rock-Eval data: example from Duvernay Formation in the Western Canada Sedimentary Basin. AAPG Bull. 2016;165:405-22. https://doi.org/10.1306/08261514173.

Chen JQ, Pang XQ, Pang H, et al. Hydrocarbon evaporative loss evaluation of lacustrine shale oil based on mass balance method: Permian Lucaogou Formation in Jimusaer Depression, Junggar Basin. Mar Pet Geol. 2018;91:422-31. https://doi.org/10.1016/j.marpe tgeo.2018.01.021.

Chen JQ, Pang XQ, Pang H, et al. A new method for unconventional tight oil assessment with application to Lucaogou Formation in Jimusaer Depression in Junggar Basin, China. AAPG Bull. 2020. https://doi.org/10.1306/12191917401.

Dubinin MM. The potential theory of adsorption of gases and vapors for adsorbents with energetically nonuniform surfaces. Chem Rev. 1960;60(2):235-41. https://doi.org/10.1021/cr60204a006.

Eseme E, Krooss BM, Littke R. Evolution of petrophysical properties of oil shales during high-temperature compaction tests: implications 
for petroleum expulsion. Mar Pet Geol. 2012;31(1):110-24. https ://doi.org/10.1016/j.marpetgeo.2011.11.005.

Helgeson HC, Knox AM, Owens CE, et al. Petroleum, oil field waters, and authigenic mineral assemblages: are they in metastable equilibrium in hydrocarbon reservoirs. Geochim Cosmochim Acta. 1993;57(14):3295-339. https://doi.org/10.1016/00167037(93)90541-4.

Huang HP, Zhang SC, Su J. Palaeozoic oil-source correlation in the Tarim Basin, NW China: a review. Org Geochem. 2016;94:32-46. https://doi.org/10.1016/j.orggeochem.2016.01.008.

Hunt JM. The origin of petroleum in carbonate rocks, vol. 9. Amsterdam: Elsevier; 1967. p. 225-51. https://doi.org/10.1016/s0070 -4571(08)71034-3.

Hunt JM. Petroleum geochemistry and geology. 2nd ed. New York: Freeman; 1995. p. 323-641.

Huo ZP, Pang XQ, Zhang BS, et al. Evidences on effective carbonate source rock of low organic matter abundance and its lower limit of TOC. Geol Rev. 2013;59(6):1165-76. https://doi.org/10.16509 /j.georeview.2013.06.025 (in Chinese).

Huo ZP, Pang XQ, Chen JQ, et al. Carbonate source rock with low total organic carbon content and high maturity as effective source rock in China: A review. J Asian Earth Sci. 2019. https://doi. org/10.1016/j.jseaes.2019.01.038.

Jarvie DM. Components and processes affecting producibility and commerciality of shale resource systems. Geol Acta. 2014;12(4):30725. https://doi.org/10.1344/geologicaActa2014.12.4.3.

Jeffrey SS. Organic-inorganic interactions in petroleum-producing sedimentary basins. Nature. 2003;426:327-33. https://doi. org/10.1038/nature02132.

Jiang ZX, Pang XQ, Jin ZJ, et al. Threshold control over hydrocarbons and its application in distinguishing valid source rock. Earth Sci J China Univ Geosci. 2002;27(6):689-95. https://doi.org/10.3321/j. issn:1000-2383.2002.06.006 (in Chinese).

Jiang FJ, Jiang ZX, Pang XQ, et al. Residual hydrocarbon in the middle-shallow source rocks in the Binbei region of the Songliao Basin and its geologic implication. JJPI. 2006;28(3):193-6. https ://doi.org/1000-9752(2006)03-0193-04 (in Chinese).

Jiang CQ, Chen ZH, Mort A, et al. Hydrocarbon evaporative loss from shale core samples as revealed by Rock-Eval and thermal desorption-gas chromatography analysis: its geochemical and geological implications. Mar Pet Geol. 2016;70:294-303. https ://doi.org/10.1016/j.marpetgeo.2015.11.021.

Jiang H, Pang XQ, Yu R, et al. Lower limit of hydrocarbon accumulation in the Kuqa Depression, Tarim Basin, NW China. Geol J. 2017;52(1):141-53. https://doi.org/10.1002/gj.2740.

Jones RW. Comparison of carbonate and shale source rocks: In: Palacas J, editor. Petroleum geochemistry and sourcerock potential of carbonate rocks. AAPG studies in geology, vol. 18; 1984. p. 163-180. https://doi.org/10.1306/ad460ea4-16f7-11d7-86450 $00102 \mathrm{c} 1865 \mathrm{~d}$

Katz BJ. Limitations of 'Rock-Eval' pyrolysis for typing organic matter. Org Geochem. 1983;4(3-4):195-9. https://doi.org/10.1016/01466380(83)90041-4.

Li M, Yao H, Fowler MG, et al. Geochemical constraints on models for secondary petroleum migration along the Upper Devonian Rimbey-Meadowbrook reef trend in central Alberta, Canada. Org Geochem. 1998;29(1):163-82. https://doi.org/10.1016/s0146 -6380(98)00094-1.

Li SM, Pang XQ, Yang HJ, et al. Characteristics and genetic type of the oils in the Tazhong uplift. Earth Sci J China Univ Geosci. 2008;33(5):635-42. https://doi.org/10.3321/j.issn:10002383.2008.05.006 (in Chinese).

Li SM, Pang XQ, Jin ZJ, et al. Petroleum source in the Tazhong Uplift, Tarim Basin: new insights from geochemical and fluid inclusion data. Org Geochem. 2010;41(6):531-53. https://doi.org/10.1016/j. orggeochem.2010.02.018.
Li SM, Amrani A, Pang XQ, et al. Origin and quantitative source assessment of deep oils in the Tazhong Uplift, Tarim Basin. Org Geochem. 2015;78:1-22. https://doi.org/10.1016/j.orggeochem 2014.10.004

Li MW, Chen ZH, Cao TT, et al. Expelled oils and their impacts on Rock-Eval data interpretation, Eocene Qianjiang Formation in Jianghan Basin. China. Int J Coal Geol. 2018;191:37-48. https:// doi.org/10.1016/j.coal.2018.03.001.

Lin CS, Yang H, Liu JY, et al. Sequence architecture and depositional evolution of the Ordovician carbonate platform margins in the Tarim Basin and its response to tectonism and sea-level change. Basin Res. 2012;24(5):559-82. https://doi.org/10.111 1/j.1365-2117.2011.00536.x.

Liu DH, Shi JY. Discussion on unconventional evaluation methods of highly mature carbonate source rocks. Petrol Explor Dev+. 1994;21(3):113-5 (in Chinese).

Liu P, Wang XF, Fang X. A new method to measure the value of organic abundance in carbonate rocks. Acta Sedimentol Sin. 2016;34(1):200-6. https://doi.org/10.14027/j.cnki. cjxb.2016.01.019 (in Chinese)

Liu WH, Teng GE, Wang XF. New knowledge of hydrocarbon generating theory of organic matter in Chinese marine carbonates. Pet Explor Dev. 2017;44(1):155-64. https://doi.org/10.1016/s1876 -3804(17)30020-4 (in Chinese).

Liu WX, Cao J, Wang M, et al. A review of carbonates as hydrocarbon source rocks: basic geochemistry and oil-gas generation. Pet Sci. 2019;16(04):713-28. https://doi.org/10.1007/s1218 2-019-0343-5.

Loucks RG, Reeds RM. Scanning-electron-microscope petrographic evidence for distinguishing organic-matter pores associated with depositional organic matter versus migrated organic matter in mudrocks. GCAGS J. 2014;3:51-60.

Modica CJ, Lapierre SG. Estimation of kerogen porosity in source rocks as a function of thermal transformation: example from the Mowry Shale in the Powder River Basin of Wyoming. AAPG Bull. 2012;96:87-108. https://doi.org/10.1306/04111110201.

Palacas JG. Petroleum geochemistry and source rock potential of carbonate rocks. AAPG Stud Geol. 1984;1-208.

Pang XQ. Theory and application of hydrocarbon expulsion threshold control hydrocarbon. Beijing: Petroleum Industry Press; 1995. p. 8-147 (in Chinese).

Pang XQ, Chen ZM, Chen FJ. Digital modeling the sedimentary history and thermal evolution, hydrocarbons generation, residence as well as expulsion procedure, and quantitative evaluation of source rocks in oil and gas bearing basins. Beijing: Geological Publishing House; 1993. p. 99-112 (in Chinese).

Pang XQ, Li MW, Li SM. Geochemistry of petroleum systems in the Niuzhuang south slope of Bohai Bay Basin: part 3. Estimating petroleum expulsion from the Shahejie Formation. Org Geochem. 2005;36(4):497-510. https://doi.org/10.1016/j.orggeochem .2004.12.001

Pang XQ, Yu QH, Guan XY, et al. Evolution and movement of source kitchens and their control of oil and gas in the Tarim Cratonic Basin, China. Energy Explor Exploit. 2012;30(2):239-72. https ://doi.org/10.1260/0144-5987.30.2.239.

Pang H, Chen JQ, Pang XQ, et al. Key factors controlling hydrocarbon accumulations in Ordovician carbonate reservoirs in the Tazhong area, Tarim Basin, western China. Mar Pet Geol. 2013;43:88-101. https://doi.org/10.1016/j.marpetgeo.2013.03.002.

Pang XQ, Li QW, Chen JF, et al. Recovery method of original TOC and its application in source rocks at high mature-over mature stage in deep petroliferous basins. J Palaeogeogr. 2014;6(6):769-89. https ://doi.org/10.7605/gdlxb.2014.06.062 (in Chinese).

Pang XQ, Chen JQ, Li SM, et al. Evaluation method and application of the relative contribution of marine hydrocarbon source rocks in the Tarim Basin: a case study from the Tazhong area. 
Mar Pet Geol. 2016;77:1-18. https://doi.org/10.1016/j.marpe tgeo.2016.05.023.

Pang XQ, Chen JQ, Li SM, et al. Crude oil sources of giant marine oilfield in Tarim Basin: evidences and relative contribution evaluation of deep present-day low-TOC source rocks. Acta Pet Sin. 2018;39(1):23-41. https://doi.org/10.7623/syxb201801003 (In Chinese with English Abstract).

Peng PA, Liu DY, Qin Y, et al. Low limits of organic carbon content in carbonate as oil and gas source rocks. Geochemistry. 2008;37(4):415-22. https://doi.org/10.3321/j.issn:03791726.2008.04.015 (in Chinese).

Peters KE, Moldowan JM. The biomarker guide: interpreting molecular fossils in petroleum and ancient sediments. New Jersey: Englewood Cliffs; 1993. https://doi.org/10.5860/choice.30-2690.

Qin JZ, Liu BQ, Guo JY, et al. Discussion on the evaluation standards of carbonate source rocks. Pet Geol Exp. 2004;26(3):281-286 (in Chinese).

Qiu ZJ, Zhang YW, Li GY, et al. Enlightenment from petroleum geology investigation of Tengiz and Yurubchenskoye carbonate oil-gas fields on exploring Giant oil-gas fields in Tarim Basin. Mar Orig Pet Geol. 1998;3(1):49-56 (in Chinese).

Robert H, Zoback M. Adsorption of methane and carbon dioxide on gas shale and pure mineral samples. J Unconv Oil Gas Resourc. 2014;8:14-24. https://doi.org/10.1016/j.juogr.2014.06.001.

Ronov AB. Organic carbon in sedimentary rocks (in relation to the presence of petroleum). Geochemistry. 1958;5:497-509.

Ross DJ, Bustin RM. The importance of shale composition and pore structure upon gas storage potential of shale gas reservoirs. Mar Pet Geol. 2009;26(6):916-27. https://doi.org/10.1016/j.marpe tgeo.2008.06.004.

Schettler PD, Parmely CR, Juniata C. Contributions to total storage capacity in Devonian shales. SPE paper; 1991. p. 23-42. https:// doi.org/10.2118/23422-ms.

Surdam RC, Boese SW, Crossey LJ. The chemistry of secondary porosity: part 2 . Aspects of porosity modification. AAPG Mem. 1984;37:127-49.

Tao CZ, Bai GP, Wang DP, et al. A comparison of hydrocarbon accumulation characteristics of Paleozoic marine carbonate in Tarim Basin and Williston Basin. Oil Gas Geol. 2013;4(4):431-40. https ://doi.org/10.11743/ogg20130402 (in Chinese).

Tian J, Chen JQ, Jiao J, et al. Comparison of the surface and underground natural gas occurrences in the Tazhong Uplift of the Tarim Basin. Acta Geol Sin (Engl Ed). 2010;84(5):1097-115. https://doi. org/10.1111/j.1755-6724.2010.00283.x.

Tissot BP, Welte DH. Petroleum Formation and Occurrence. Berlin: Springer-Vevlag; 1978. p. 1-554.

Tissot BP, Welte DH. Petroleum Formation and Occurrence: a new approach to oil and gas exploration. Berlin: Springer; 1984.

Trask PD. Origin and environment of source sediments. Tulsa: AAPG; 1933.

Vandegrift GF, Horwitz EP. Interfacial activity of liquid-liquid extraction reagents-I: dialkyl phosphorous based acids. J Inorg Nucl Chem. 1980;42(1):119-25. https://doi.org/10.1016/00221902(80)80056-x.
Wang TG, Zhang BS, Li MJ. Migration and accumulation of the Ordovician hydrocarbons in Halahatang and the peripheral Area, Tarim Basin. Beijing: Personal communication; 2014. p. 53-55.

Wang ZM, Xiao ZY. A comprehensive review concerning the problem of marine crude oil source in Tarim Basin. Chin Sci Bull. 2004;49:1-9. https://doi.org/10.1360/04wd0335.

Wang YS, Li Z, Gong JQ, et al. Discussion on an evaluation method of shale oil and gas in Jiyang depression: a case study on Luojia area in Zhanhua sag. Acta Pet Sin. 2013;34(1):83-91. https://doi. org/10.7623/syxb201301009 (in Chinese).

Wang ZM, Li MQ, Yang HJ, et al. Hydrocarbon enrichment rules and exploration potential prediction of superimposed basins in western China. Beijing: Personal communication; 2015.

Wang DP, Lu HM, Chen XL, et al. Petroleum accumulation systems and distribution of medium to large marine carbonate fields. Oil Gas Geol. 2016;37(3):363-71. https://doi.org/10.11743/ogg20 160308 (in Chinese)

Xue HT, Tian SS, Wang WM, et al. Correction of oil content-one key parameter in shale oil resource assessment. Oil Gas Geol. 2016;37(1):15-22. https://doi.org/10.11743/ogg20160103 (in Chinese with English abstract).

Yang HJ. Recent exploration achievements and development schedule. Beijing: Personal communication; 2012.

Zhang SC, Hanson AD, Moldowan JM. Paleozoic oil-source correlations in the Tarim Basin, NW China. Org Geochem. 2000;31(4):273-86. https://doi.org/10.1016/s0146 -6380(00)00003-6.

Zhang SC, Liang DG, Zhang DJ. Evaluation criteria for Paleozoic effective hydrocarbon source rocks. Pet Explor Dev. 2002a;29(2):812. https://doi.org/10.3321/j.issn:1000-0747.2002.02.002 (in Chinese).

Zhang SC, Liang DG, Li MW, et al. Molecular fossils and oil-source rock correlations in Tarim Basin. Chin Sci Bull. 2002b;47:1623. https://doi.org/10.3321/j.issn:0023-074x.2002.z1.003 (in Chinese).

Zhang SC, Liang DG, Zhang BM, et al. The generation of marine oil and gas in Tarim Basin. Beijing: Petroleum Industry Press; 2004. p. 270-340 (in Chinese).

Zhang M, Huang GH, Zhao HJ, et al. Quantitative identification pattern and its significance of marine mixed oils in Tarim Basin. JJPI. 2007;29(4):34-9. https://doi.org/10.3969/j.issn.10009752.2007.04.006 (in Chinese).

Zhao MJ, Wang ZM, Pan WQ, et al. Lower palaeozoic source rocks in Manjiaer sag, Tarim Basin. Pet Explor Dev. 2008;35(4):417-23. https://doi.org/10.1016/s1876-3804(08)60089-0.

Zhu GY, Cui J, Yang HJ, et al. The distribution and origin of Cambrian crude oil in North Tarim Basin. Acta Sedimentol Sin. 2011;27(08):2435-46. https://doi.org/1000-0569/2011/027(08)2435-46 (in Chinese).

Zou CN, Tao SZ, Hou LH. Unconventional petroleum geology. 2nd ed. Beijing: Geological Publishing House; 2013. p. 61-126 (in Chinese). 